\title{
Sulfur isotope variations from orebody to hand-specimen scale at the Mežica lead-zinc deposit, Slovenia: a predominantly biogenic pattern
}

\author{
Uroš Herlec $\cdot$ Jorge E. Spangenberg $\cdot$ Jošt V. Lavrič
}

Received: 20 January 2010 /Accepted: 24 May 2010 /Published online: 11 June 2010

(C) Springer-Verlag 2010

\begin{abstract}
The Mississippi Valley-type (MVT) Pb-Zn ore district at Mežica is hosted by Middle to Upper Triassic platform carbonate rocks in the Northern Karavanke/Drau Range geotectonic units of the Eastern Alps, northeastern Slovenia. The mineralization at Mežica covers an area of $64 \mathrm{~km}^{2}$ with more than 350 orebodies and numerous galena and sphalerite occurrences, which formed epigenetically, both conformable and discordant to bedding. While knowledge on the style of mineralization has grown considerably, the origin of discordant mineralization is still debated. Sulfur stable isotope analyses of 149 sulfide samples from the different types of orebodies provide new insights on the genesis of these mineralizations and their
\end{abstract}

Editorial handling: B. Lehmann

Electronic supplementary material The online version of this article (doi:10.1007/s00126-010-0290-y) contains supplementary material, which is available to authorized users.

\section{U. Herlec}

Department of Geology, University of Ljubljana,

Aškerčeva 12,

SI-1000 Ljubljana, Slovenia

e-mail: uros.herlec@gmail.com

J. E. Spangenberg $(\bowtie) \cdot J$. V. Lavrič

Institute of Mineralogy and Geochemistry,

University of Lausanne,

Bâtiment Anthropole,

CH-1015 Lausanne, Switzerland

e-mail: Jorge.Spangenberg@unil.ch

J. V. Lavrič

e-mail: jlavric@bgc-jena.mpg.de

Present Address:

J. V. Lavrič

Max Planck Institute for Biogeochemistry,

Hans-Knöll-Str. 10,

07745 Jena, Germany relationship. Over the whole mining district, sphalerite and galena have $\delta^{34} S$ values in the range of -24.7 to $-1.5 \%$ o VCDT $(-13.5 \pm 5.0 \%$ ) and -24.7 to $-1.4 \%$ o $(-10.7 \pm 5.9 \%$ ), respectively. These values are in the range of the main MVT deposits of the Drau Range. All sulfide $\delta^{34} S$ values are negative within a broad range, with $\delta^{34} S_{\text {pyrite }}<\delta^{34} S_{\text {sphalerite }}$ $<\delta^{34} S_{\text {galena }}$ for both conformable and discordant orebodies, indicating isotopically heterogeneous $\mathrm{H}_{2} \mathrm{~S}$ in the ore-forming fluids and precipitation of the sulfides at thermodynamic disequilibrium. This clearly supports that the main sulfide sulfur originates from bacterially mediated reduction (BSR) of Middle to Upper Triassic seawater sulfate or evaporite sulfate. Thermochemical sulfate reduction (TSR) by organic compounds contributed a minor amount of ${ }^{34} \mathrm{~S}$-enriched $\mathrm{H}_{2} \mathrm{~S}$ to the ore fluid. The variations of $\delta^{34} S$ values of galena and coarse-grained sphalerite at orefield scale are generally larger than the differences observed in single hand specimens. The progressively more negative $\delta^{34} S$ values with time along the different sphalerite generations are consistent with mixing of different $\mathrm{H}_{2} \mathrm{~S}$ sources, with a decreasing contribution of $\mathrm{H}_{2} \mathrm{~S}$ from regional TSR, and an increase from a local $\mathrm{H}_{2} \mathrm{~S}$ reservoir produced by BSR (i.e., sedimentary biogenic pyrite, organo-sulfur compounds). Galena in discordant ore $(-11.9$ to $-1.7 \%$; $-7.0 \pm 2.7 \%$ o, $n=12)$ tends to be depleted in ${ }^{34} S$ compared with conformable ore ( -24.7 to $-2.8 \%,-11.7 \pm$ $6.2 \%, n=39$ ). A similar trend is observed from finecrystalline sphalerite I to coarse open-space filling sphalerite II. Some variation of the sulfide $\delta^{34} S$ values is attributed to the inherent variability of bacterial sulfate reduction, including metabolic recycling in a locally partially closed system and contribution of $\mathrm{H}_{2} \mathrm{~S}$ from hydrolysis of biogenic pyrite and thermal cracking of organo-sulfur compounds. The results suggest that the conformable orebodies originated by mixing of hydrothermal saline metal-rich fluid with $\mathrm{H}_{2} \mathrm{~S}$ rich pore waters during late burial diagenesis, while the 
discordant orebodies formed by mobilization of the earlier conformable mineralization.

Keywords Sulfur isotopes $\cdot$ Sulfides $\cdot$ Sulfates $\cdot \mathrm{Pb}-\mathrm{Zn}$ mineralization $\cdot$ MVT $\cdot$ Mežica $\cdot$ Slovenia

\section{Introduction}

The sulfur isotope composition of sulfur-bearing ore and gangue minerals of carbonate-hosted $\mathrm{Pb}$ and $\mathrm{Zn}$ Mississippi Valley-type (MVT) deposits may provide valuable information on the source and reduction mechanism of sulfur, as well as some insight into the composition of the ore fluid (s), fluid/fluid mixing processes, fluid pathways, and physicochemistry of the ore-bearing fluid during the precipitation of sulfides (e.g., Ohmoto and Rye 1979; Ohmoto et al. 1985; Ohmoto and Goldhaber 1997; Anderson 2008; Anderson and Thom 2008). The Middle Triassic platform carbonate rocks of the Northern Karavanke/Drau Range geotectonic units of the Eastern Alps host a large number of low-temperature $\mathrm{Pb}$ and $\mathrm{Zn}$ deposits, ranging in size from small uneconomic prospects to large MVT deposits, such as Bleiberg in Austria, Mežica in Slovenia, and Raibl and Salafossa in Italy (Fig. 1; Bechstädt and Döhler-Hirner 1983; Cerny 1989; Fontboté and Boni 1994). Uneconomic ore occurrences are in the Late Triassic Dachstein limestone and Hauptdolomit of the Northern Karavanke nappe. The Bleiberg and Mežica $\mathrm{Pb}-$ $\mathrm{Zn}$ deposits occur within reef and lagoonal carbonate rocks of the Ladinian Wetterstein Formation. The Mežica MVT deposit is located in the eastern part of Alpine MVT province about $55 \mathrm{~km}$ northeast of Ljubljana in northeastern Slovenia $\left(46^{\circ} 30^{\prime} \mathrm{N}, 14^{\circ} 46^{\prime} \mathrm{E}\right.$; Fig. 1). Mežica includes more than 350 orebodies and numerous occurrences within an area of $64 \mathrm{~km}^{2}$ which are conformable and/or discordant to bedding (Fig. 2). The accumulated production was about 19 million metric tons $(\mathrm{Mt})$ of ore grading $5.3 \mathrm{wt} \% \mathrm{~Pb}$ and $2.7 \mathrm{wt} \% \mathrm{Zn}$. The orefield is the second largest deposit in the Alpine carbonate-hosted $\mathrm{Pb}-\mathrm{Zn}$ province of the Eastern Alps and is only surpassed by Bleiberg. After 350 years of mining activity, the exploitation of Mežica ore stopped in 1994, and the mine was closed in 2004. The small Topla $\mathrm{Zn}-\mathrm{Pb}$ deposit $(250,150 \mathrm{t}$ ore grading $10 \mathrm{wt} \% \mathrm{Zn}$ and $3.3 \mathrm{wt} \% \mathrm{~Pb}), 2 \mathrm{~km}$ to the west of the Mala Peca orebody of the Mežica main deposit, is hosted by Anisian carbonate rocks. A recent extensive geochemical study of the Topla and Mežica deposits was performed to evaluate the relations between these deposits and obtain further information on the composition of the ore fluids and the mechanisms of ore precipitation. The study included carbonate trace and rare earth element compositions, $\mathrm{C}$ and $\mathrm{O}$ stable isotope ratios of the carbonates $\left({ }^{13} \mathrm{C} /{ }^{12} \mathrm{C}\right.$,
${ }^{18} \mathrm{O} /{ }^{16} \mathrm{O}$ ), Rock-Eval pyrolysis parameters, distribution of hydrocarbon biomarkers, bulk organic ${ }^{13} \mathrm{C} /{ }^{12} \mathrm{C}$ and ${ }^{15} \mathrm{~N} /{ }^{14} \mathrm{~N}$, and compound specific ${ }^{13} \mathrm{C} /{ }^{12} \mathrm{C}$ of individual hydrocarbons. The combined data provided supporting evidence that Topla and Mežica were formed from a typical lowtemperature MVT brine in two different ore-forming processes. The early diagenetic Topla deposit formed in the Anisian stage in an anoxic supratidal saline to hypersaline environment, where ore deposition was caused by the mixing of the incoming hydrothermal metal-rich fluid with bacterial $\mathrm{H}_{2} \mathrm{~S}$-rich pore waters (Spangenberg and Herlec 2006). The knowledge of the clearly epigenetic mineralization at Mežica-mainly based on studies of orebodies conformable to bedding - has grown considerably recently (Kuhlemann et al. 2001; Spangenberg and Herlec 2006). It was formed during an epigenetic process during the initial phase of the Pliensbachian rifting. The origin and timing of discordant ore formation is unclear (Drovenik 1983). The mineralization in conformable orebodies originated from hot $\left(122^{\circ} \mathrm{C}\right.$ to $\left.159^{\circ} \mathrm{C}\right)$ and saline $(22$ to $26 \mathrm{wt} \%$ eq. $\mathrm{NaCl}$ ) metalliferous brines during deep burial diagenesis (Zeeh et al. 1998). The discordant mineralizations largely infill postTriassic and post-first-ore-phase faults, suggesting that they formed from remobilization of earlier (conformable) ore during later hydrothermal events (Drovenik 1983). In this communication, we compile the published sulfur isotope composition for the Mežica MVT deposit and present the results of a new comprehensive sulfur isotope study of sulfides from orebody down to hand-specimen scale, aimed to contribute to a better understanding of the sulfur sources and the relationship between the orebodies of different morphology and stratigraphic position. Our results complement previously reported organic and inorganic geochemical patterns of the Topla-Mežica MVT deposits (Spangenberg and Herlec 2006) and support the conclusion that biogenic reduction of sulfate was the main sulfide sulfur source to the ore fluid.

\section{Geologic setting}

The Mežica orebodies are hosted within the upper $600 \mathrm{~m}$ of the more than 1,200-m thick platform carbonates of the Ladinian to early Carnian Wetterstein Formation, Northern Karavanke (Štrucl 1970, 1974; Drovenik et al. 1980; Cerny et al. 1982; Cerny 1989; Spangenberg and Herlec 2006). The Northern Karavanke Mts are part of the uppermost structural unit of the Eastern Alps and belong to the Drau Range tectonic unit. Predominant mechanisms of deformation in the Northern Karavanke Mts is brittle faulting and thrusting mainly related to motion along the Periadriatic fault zone (PFZ) south of the mineralized area. The PFZ is one of the most prominent structures in the Alps. In the 


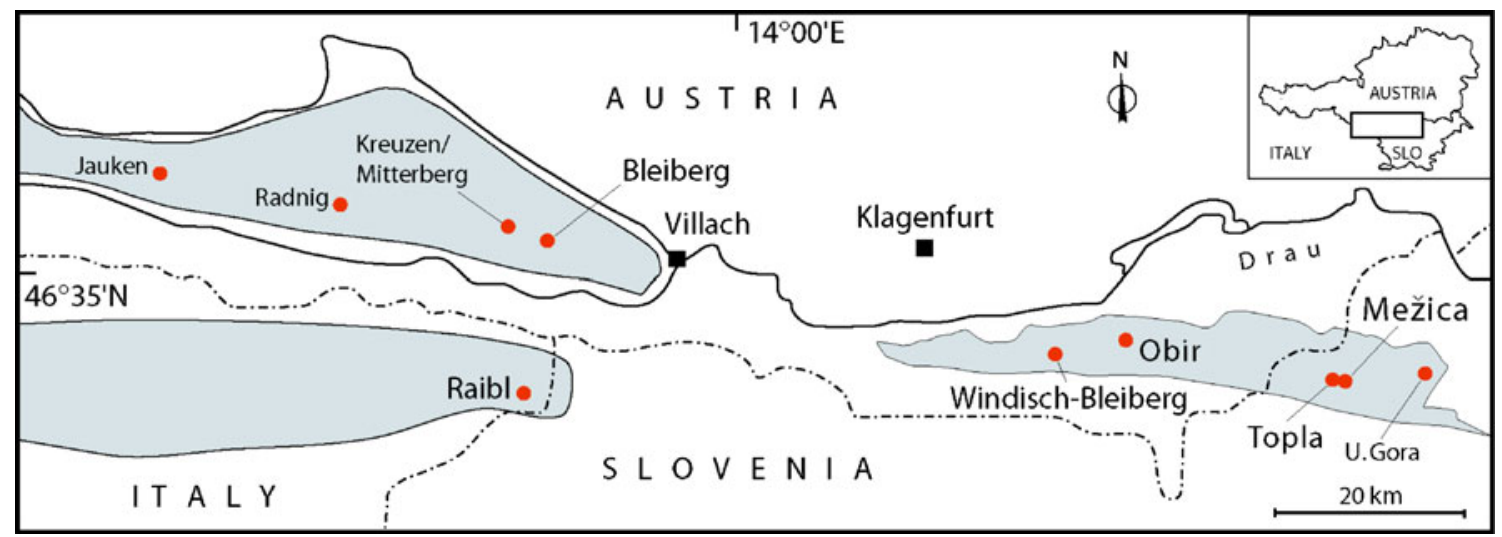

Fig. 1 Location of the main low-temperature carbonate-hosted (Mississippi Valley-type) $\mathrm{Pb}-\mathrm{Zn}$ districts in the northern Karavanke/Drau Range geotectonic units and Eastern and Southern Alps

studied area, it divides the Southern Alps from the northerly lying Eastern Alps. The PFZ formed in the youngest, postcollisional stage of tectonic development of the Alps, which started approximately 35 Ma ago, when the heavy subducted oceanic slab broke off and sunk into the mantle, generating tonalite and granodiorite intrusions (Fodor et al. 1998). In early Miocene, the indenting Adriatic litosphere split the European lithosphere longitudinally, producing vertical extrusion of the Central Alps and backthrusting of the Southern Alps towards the south. During Oligocene and

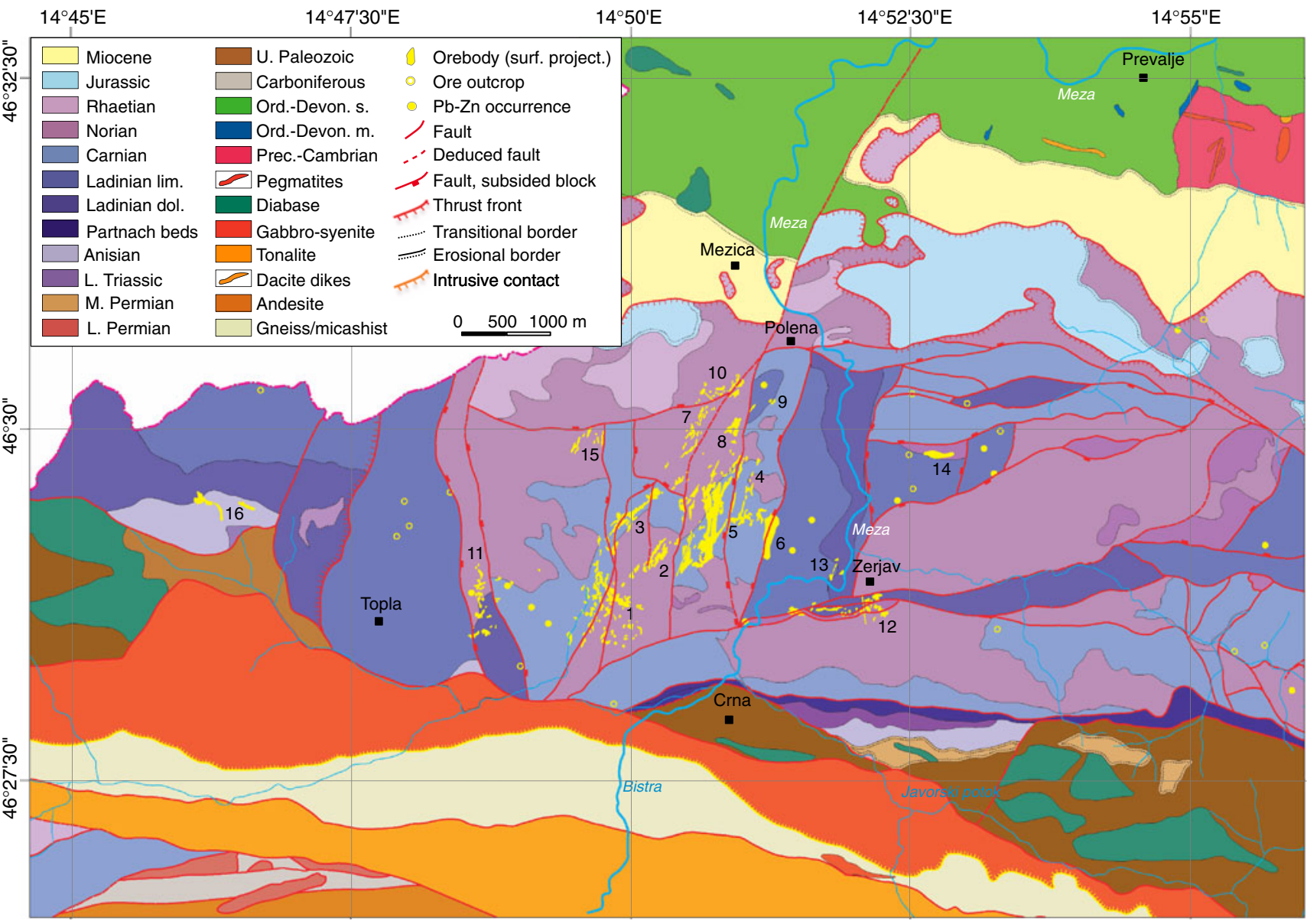

Fig. 2 Simplified geological map of the Mežica deposit showing the distribution of main orebodies: 1 Naveršnik, 2 Srednja cona, 3 Helena-Triurno, 4 Union, Moring, Igrče, Helena, 5 Igrče, 6 Staro
Igrče, 7 Fridrih, 8 Srce, 9 Marhovče, 10 Stari Fridrih, 11 Peca, 12 Graben, 13 Ravšerjevo, 14 Mučevo, 15 Luskačevo, 16 Topla. The lithologies are described in the text. Modified from Štrucl (1970) 
Miocene, the Eastern Alps were extruded in eastward direction by dextral strike slip on the PFZ. The Northern Karavanke palm structure with its Peca nappe and North Karavanke nappes results from pre-Oligocene sinistral strike-slip tectonics and late Pliocene dextral strike-slip transpressive reactivation causing vertical extrusion and thrusting northwards above Sarmatian and even Quaternary sediments (Fodor et al. 1998).

The rocks in the Mežica ore district belong to a fore-reef, reef, and prevailing lagoonal sedimentary facies of a carbonate platform (Fig. 2). Sea level oscillation caused cyclothemic sedimentation of supratidal breccias, stromatolites and biomicritic limestones, and shallow karstification of the emerged sediments. Precambrian and Cambrian gneisses and micaschists with minor lenticular bodies of marbles of the Pohorje Formation are exposed in the northeastern part of the area. Regionally metamorphosed Early to Middle Jurassic pegmatite dikes (Pegmatites in Fig. 2) formed by partial melting of the metapelites around 186 to $172 \mathrm{Ma}$ (Vrabec and Herlec 2007). The Silurian to Devonian Štalenska gora formation north of the mineralized area consists of violet and green mafic tuffitic clayey schists (Ord.-Devon. s. in Fig. 2), occasionally altered into metamarlstone and marbles (Ord.-Devon. m. in Fig. 2) containing diabase dikes and sills of spilitic character (Diabase in Fig. 2). This formation is dissected by some dacite dikes of Miocene age (Dacite dikes in Fig. 2). The Upper Paleozoic low-grade metamorphic sequence to the south of the mineralized area is made up of schists with thin marble layers (U. Paleozoic in Fig. 2), metabasaltic pillow lavas, and metadiabase intrusions (Diabase in Fig. 2). Within the Železna kapla (Eisenkappel) magmatic and metamorphic zone south of the mineralized area, there are two magmatic units of different age and lithology and a contactmetamorphic body. The northern magmatic intrusive body is of Upper Permian to Triassic age (244-224 Ma, Vrabec and Herlec 2007; gabbro-syenite in Fig. 2). Intrusive breccias of syenogranite and syenite with rapakivi texture and with enclaves of mafic and intermediate composition prove interaction of mafic and felsic magma. Contactmetamorphic rocks of the Železna kapla (Eisenkappel) magmatic zone (Gneiss/micaschist in Fig. 2) are to the north in contact with Late Permian to Early Triassic intrusive breccias formed by gabbroic to syenitic components and to the south in tectonic contact with tonalite. They were formed by contact metamorphism of schists into finegrained biotite gneiss and micaschist. The post-orogenic tonalites of the Železna kapla magmatic zone (Tonalite in Fig. 2) were emplaced during the Oligocene along the PFZ.

The Tethyan cycle of sedimentation with MVT Pb and $\mathrm{Zn}$ mineralization started with clastic sedimentation of the Middle Permian Gröden Formation (M. Permian in Fig. 2) unconformably overlying Upper Paleozoic low-grade meta- morphic rocks (U. Paleozoic in Fig. 2). Marlstone, sandstone, and carbonate rocks of the Lower Triassic Werfen Formation follow (L. Triassic in Fig. 2). They are covered by Anisian dolostones and limestones, which are named Koprivna Formation in Slovenia and Alpiner Muschelkalk in Austria (Anisian in Fig. 2). There are some differences between the Anisian lithologic sequences in the Topla valley to the west and in the Javorski potok area in the eastern part of the studied area. Dolostones are present in the lower part and limestones in the upper part in both areas. Only dolostones at Topla contain early diagenetic $\mathrm{Zn}-\mathrm{Pb}$ mineralization, whereas in Javorje this horizon is characterized by widespread lenticular intercalations of intraformational dolomitic breccias with marly matrix. The overlying limestone beds have chert nodules and a thin bed of green pelitic tuff. Two different facies of Ladinian rocks follow. In the southern part, limestone with chert nodules is overlain by shales and limestone breccias from the Partnach Formation (Partnach beds in Fig. 2), which hosts some slope fore-reef breccia limestone units up to $100 \mathrm{~m}$ in length and several tens of meters wide.

The Wetterstein Formation in the central area of the Northern Karavanke Mts consists of two facies, the Wetterstein reef massive limestone and bedded back-reef to lagoonal dolostones (Wetterstein lim. and dol. in Figs. 2 and 3) occuring in the northern part. The Wetterstein and Partnach Formations are covered by three shale and carbonate horizons of the Carnian Raibl Group (Carnian in Figs. 2 and 3). The Carnian beds are uniformly covered by a succession of platy limestone, which gradually changes into the lower horizon of well-bedded stromatolitic Main Dolomite Formation (Hauptdolomit in Austria). This unit (Norian in Fig. 2) is followed by bedded limestones of the Rhaetian Dachstein Formation (Rhaetian in Fig. 2). Above the angular tectonic and erosional unconformity are Jurassic platy limestones and black shales (Jurassic in Fig. 2). Miocene clastic sediments fill up the Leše Tertiary coal basin north of the ore district and build the hills north of the Northern Karavanke Mts. Miocene beds were deposited discordantly over all Northern Karavanke Mesozoic lithologic units.

\section{The Mežica deposit}

At Mežica, the mineralization occurs as zebra ore, replacements, and open-space filling in shallow paleokarst, hydrothermal karst, veins, and breccia (Zeeh et al. 1998; Spangenberg and Herlec 2006). Five types of orebodies have been recognized: (1) reef-bound, (2) conformable with bedding, (3) discordant, (4) irregular, and (5) breccia formed by karst-cave roof collapse (Drovenik et al. 1980; Herlec 2009). Reef-bound orebodies were formed within 


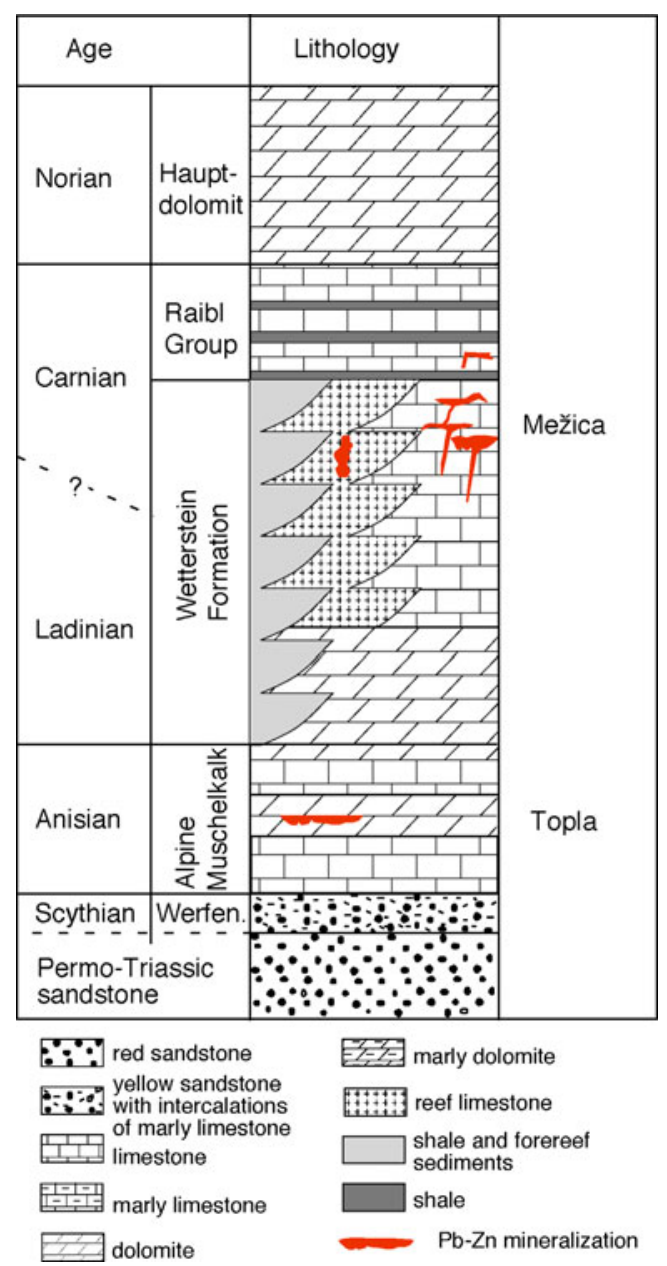

Fig. 3 Stratigraphic column in the area of Mežica deposit (modified after Štrucl 1974; Cerny 1989; and Placer et al. 2002)

the primary highly porous and permeable reef facies of the Wetterstein Formation. The conformable ore bodies are situated between 6 and $250 \mathrm{~m}$ below the first Carnian Raibl shale (Fig. 3). Some conformable orebodies (e.g., Graben, Luskačevo, and Navršnik orebodies) show clear evidence of remobilization and recrystallization of ore minerals. Mineralization also occurs as paleokarst filling and replacement in tabular or lense-shaped bodies conformable to bedding. Early Jurassic karstified faults may extend vertically over $60 \mathrm{~m}$ (e.g., in Navršnik orebody). These faults are believed to have channeled upwards the ore fluids. The discordant orebodies are situated along postEarly Jurassic faults and fault zones from the Raibl shale up to $600 \mathrm{~m}$ below its contact with the Wetterstein Formation (Figs. 2 and 3). Ore in discordant orebodies occurs mainly as fragments and cement of tectonic and dissolution breccias. After the end of formation of the first deep burial carbonate cement, the clear saddle dolomite (SD I), a Pbdominated second ore phase is observed (Fig. 3). It formed simultaneously to the discordant fissure-bound, subvertical ore bodies of the so-called Union fault system. The trace element composition of this late-formed galena indicates that most ore has been mobilized from the earlier-formed orebodies (Drovenik 1983). Large irregular and columnarbreccia orebodies formed from different tectonic and dissolution breccias as a result of selective dissolution of host carbonate by ore fluids. These fluids may have caused recrystallization and remobilization of sphalerite and galena, which were deposited in veins and open spaces. Different generations of shallow water and deep burial ore and gangue minerals are distinguished in the ore-bearing dolostones and are represented in a generalized paragenetic sequence (Fig. 4) modified after Drovenik and Pungartnik (1987), Kuhlemann (1994), and Spangenberg and Herlec (2006). The main ore minerals are sphalerite and galena, with traces of pyrite, marcasite, and greenockite. White sparry dolomite and blocky calcite are the main syn- and post-ore hydrothermal carbonate cements. The homogenization temperatures of fluid inclusions trapped in clear saddle dolomite range from $122^{\circ} \mathrm{C}$ to $147^{\circ} \mathrm{C}$ and in small sphalerite grains and brown sphalerite from $126^{\circ} \mathrm{C}$ to $159^{\circ}$ $\mathrm{C}$, with salinities ranging between 7 and $25 \mathrm{wt} \% \mathrm{NaCl}$ equiv (Zeeh et al. 1998).

Early/shallow diagenetic sphalerite and galena are only present in the Topla deposit (Spangenberg and Herlec 2006). Two burial diagenetic ore stages are recognized at Topla and Mežica (Kuhlemann and Zeeh 1995; Zeeh et al. 1998). Ore stage I in Mežica is coeval with the first generation of white sparry dolomite, replacing largely the fine-grained host carbonate. This Early Jurassic ore stage is characterized by sphalerite and is relatively poor in galena. The Lower Cretaceous ore stage II is dominated by galena, occurring mainly as coarse-crystalline open-space filling, apparently younger than the late-stage open-space filling of white calcite. Sphalerite of ore stage II occurs as very coarse euhedral crystals within the later carbonate cements. Sphalerite appears in three main generations: (1) as fine-crystalline anhedral sphalerite intergrown with fully recrystallized host-rock; (2) as coarse open-space filling subhedral sphalerite and botryoidal sphalerite predating and/or intergrown with white sparry dolomite (SD I); and (3) as very coarse euhedral crystals within the late white carbonate cement (C I). Sphalerite of the first ore stage occurs as generations I and II, and sphalerite in the second ore stage is mostly of generation III (Kuhlemann 1994). In some samples, up to seven generations of sphalerite are distinguished by different grain size and color, varying from yellow, green, red to brown (e.g., Kuhlemann 1994). Different sphalerite varieties of distinctive color, grain size, textures, and facies relations were followed throughout the whole region, which suggests they represent separated mineralizing events. 
Fig. 4 Paragenesis and mineral association of the early diagenetic Topla and epigenetic Mežica deposit (adapted from Spangenberg and Herlec 2006) $D R D$ dark replacement dolomite, $S D I$ saddle dolomite I, SD II saddle dolomite II, $C$ I blocky corrosive calcite I, $s l$ sphalerite

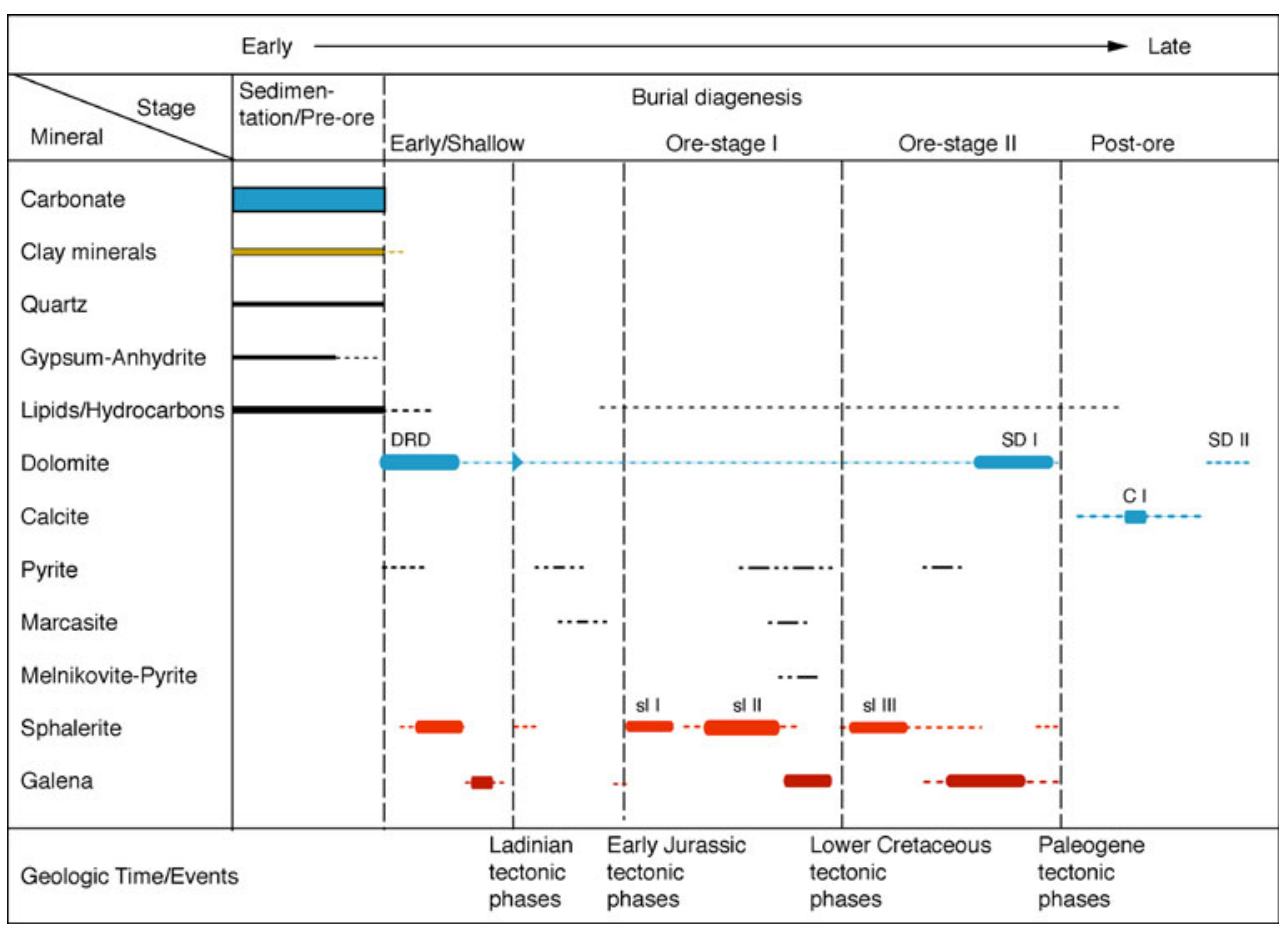

\section{Previous sulfur isotope studies at Mežica}

Previous sulfur isotope studies $\left[\delta^{34} S \%\right.$ vs. Vienna Cañon Diablo Troilite (VCDT)] of the sulfides from different orebodies and sections of the Mežica deposit report a variation between -21.1 and $-5.6 \%(-13.5 \pm 4.9)$ for sphalerite, -24.7 and $-2.8 \%$ o $(-11.1 \pm 5.9)$ for galena, and -22.4 and $-18.3 \%$ o $(-20.3 \pm 1.4)$ for pyrite (Table 1; the individual data are compiled in ESM; Drovenik et al. 1970, 1980; Kuhlemann et al. 2001). These $\delta^{34} S$ values are within the overall range for sulfides of the main MVT deposits of the Drau Range: Bleiberg ( -39.0 to $-4.1 \%$ $\delta^{34} S$, average $=-17.8 \%$ o, $\left.n=60\right)$, Raibl ( -25.6 to $-6.4 \%$ o $\delta^{34} S$, average $\left.=-17.8 \%, n=15\right)$, and Topla $(-29.0$ to $1.4 \%$ o $\delta^{34} S$, average $=-10.5 \%$, $n=74$; data from Schroll and Wedepohl 1972; Drovenik et al. 1978, Drovenik, Štrucl and Pezdič 1980; Schroll and Rantitsch 2005; Drovenik et al. 1988; Kuhlemann et al. 2001). The broad ranges of negative $\delta^{34} S$ values at Mežica were interpreted as a result of biogenic reduction of seawater sulfate (Drovenik et al. 1980; Kuhlemann et al. 2001). Kuhlemann et al. (2001) measured broad variations of the $\delta^{34} S$ values of the sulfides from regional down to centimeter-scale of the Drau Range deposits, including ten sphalerite and six galena samples from Mežica. Four galena samples and all sphalerite samples were from ore stage I, two galena samples from ore stage II. No systematic variation of the $\delta^{34} S$ values with size, color (e.g., yellow, green, orange, orange-red, dark blue, or brown), and/or relative time relationship (ore stages) of the sphalerites was observed. A single hand specimen from the Obir deposit showed $\delta^{34} S$ variations between -17.5 and $3.3 \%$ o $\left(\Delta^{34} S=14.2 \%\right.$ ) in the different sphalerite generations. However, the studied hand specimen from Mežica (Graben orebody) had sphalerite $\delta^{34} S$ values in a narrow range, between -21.1 and $-18.1\left(\Delta^{34} S=3 \%,-19.2 \pm 1.3 \%, n=6\right)$. Schroll et al. (1983) report similar isotopic differences $\left(\Delta^{34} S\right.$ up to $19.6 \%$ ) at the hand-specimen scale in sphalerite generations from Bleiberg (sphalerite I, $-4.1 \%$; sphalerite II, $-12.8 \%$; sphalerite III, $-23.7 \%$ ). These small-scale isotopic differences point to local $\delta^{34} S$ variations of the sulfur sources during sulfide-precipitation, without excluding mixing of different sulfur sources.

\section{Materials and methods}

Fifty-three ore samples from conformable and discordant orebodies were selected for the sulfur isotope study. Twenty-one samples were taken from mine walls at different levels, and 32 samples, mostly from exhausted orebodies and inaccessible areas of the mine, were obtained from collections of the Department of Geology of the University of Ljubljana. The sulfur minerals, including sphalerite, galena, pyrite, and marcasite, were separated manually after cutting a fresh surface, examined under a binocular for the presences of impurities or different sulfur phases, and ground to fine powder using an agate mortar and pestle. Five samples of greenockite and four of gypsum 
Table 1 Published sulfur isotope composition from the Mežica ore deposit in previous studies

\begin{tabular}{|c|c|c|c|c|c|c|}
\hline \multirow[t]{3}{*}{ Orebody/section } & \multirow[t]{3}{*}{ Orebody morphology } & \multicolumn{5}{|l|}{$\delta^{34} \mathrm{~S}$} \\
\hline & & \multicolumn{5}{|c|}{$(\%, \mathrm{VCDT})$} \\
\hline & & Min & Max & Mean & $\mathrm{SD}$ & $n$ \\
\hline Galena & Conformable & -24.7 & -2.8 & -11.1 & 5.9 & 47 \\
\hline Galena & Discordant & -7.9 & -1.7 & -5.6 & 2.6 & 4 \\
\hline Spahlerite & Conformable & -21.1 & -5.6 & -13.5 & 4.0 & 33 \\
\hline Pyrite & Conformable & -22.4 & -18.3 & -20.2 & 1.4 & 7 \\
\hline Barite & & 12.2 & 17.3 & 14.7 & 3.6 & 2 \\
\hline
\end{tabular}

were included. The generations of sphalerite were studied in detail in selected hand specimens of zebra ore and breccia ore. A total of 149 sulfide samples were analyzed for their sulfur isotope composition at the Institute of Mineralogy and Geochemistry of the University of Lausanne using a Carlo Erba 1108 elemental analyzer (EA) connected to a Thermo Fisher (formerly ThermoQuest/ Finnigan, Bremen, Germany) Delta $\mathrm{S}$ isotope ratio mass spectrometer (IRMS) that was operated in the continuous helium flow mode via a Conflo III split interface (EA-IRMS). The stable isotope composition of sulfur is reported in the delta $(\delta)$ notation as the per mil (\%) deviation of the isotope ratio relative to known standards: $\delta=\left[\left(R_{\text {sample }}-R_{\text {standard }}\right) / R_{\text {standard }}\right] \times 1000$, where $R$ is the ratio of the heavy to light isotopes $\left({ }^{34} S /{ }^{32} S\right)$. The sulfur standard is the VCDT. The reference $\mathrm{SO}_{2}$ gas was calibrated against the IAEA-S-1 sulfur isotope reference standard $\left(\mathrm{Ag}_{2} \mathrm{~S}\right)$ with $\delta^{34} S$ value of $-0.3 \%$ (Coplen and Krouse 1998). The overall analytical reproducibility of the EA-IRMS analyses, assessed by replicate analyses of three laboratory standards (barium sulfate, with a working $\delta^{34} S$ value of $+12.5 \%$; pyrite $\mathrm{Ch},+6.1 \%$; pyrite $\mathrm{E},-7.0 \%$ ) is better than $\pm 0.2 \%$ ( $1 \mathrm{SD}$ ). The accuracy of the $\delta^{34} S$ analyses was checked periodically by analyses of the international reference materials IAEA-S-1 and IAEA-S-2 silver sulfides $(0.3 \%$ and $+22.7 \pm 0.2 \%$, respectively, values from IAEA-Catalogue and Documents) and NBS-123 sphalerite $(+17.09 \pm 0.31 \%$, value from NIST-Catalogue and Documents).

\section{Results}

The $\delta^{34} S$ values obtained in this study are listed in Table 2 . This data set represents the entire spectrum of the ore stages, orebody morphologies, sulfur-mineral assemblages, and sphalerite generations of the Mežica deposit. We used box plot charts, displaying the ranges, 25th and 75th percentiles (lower and upper quartiles; Q1, Q3), outliers, and median (50th percentile, Q2) to show the spread of $\delta^{34} S$ values between categories (i.e., sulfide minerals, sphalerite generations, and orebody forms). The $\delta^{34} S$ values of the analyzed sulfide (galena, sphalerite, marcasite, pyrite, and greenockite) and sulfate (gypsum) minerals are presented in Fig. 5. The sulfur isotope composition of galena $(-23.2$ to $-1.4 \%$, median $=-8.9 \%$, $n=53)$, sphalerite $(-24.6$ to $-1.5 \%$, median $=-13.2 \%$, $n=$ $72)$, marcasite $(-20.4$ to $-12.4 \%$, median $=-18.0 \%, n=9)$, and pyrite $(-29.0$ to $-15.4 \%$, median $=-22.3 \%, n=4)$ is within a $\delta^{34} S$ range of $28 \%$ (Fig. 5). At Mežica, greenockite $(\mathrm{CdS})$ is found as yellow earthy coatings in the oxidized ore and it is thought that cadmium, probably as a sulfide, is present in the sphalerite. Drovenik et al. (1980) report Cd contents of up to $0.6 \mathrm{wt} \%$ in Mežica sphalerites. The $\delta^{34} S$ values of greenockite $(-19.2$ to $-7.8 \%$, median $=-12.2 \%, n=4)$ and the late oxidation product, gypsum $(-19.5$ to $-16.1 \%$, median $=-17.0 \%$, $n=$ 4) lie in the range of the main ore sulfides. These data suggest that greenockite most probably formed as a product of hypogene oxidation of primary sphalerite. Drovenik et al. (1970, 1980) and Kuhlemann et al. (2001) reported similar values for Mežica sulfides. The $\delta^{34} S$ values of galena range from -24.7 to $-1.7 \%$, those of sphalerite from -21.1 to $-5.6 \%$, and those of pyrite and marcasite from -22.4 to $-18.3 \%$ (Table 1). A set of 210 sulfur isotope data of Mežica main ore sulfides was obtained by compiling the published data $(n=51$ for galena, $n=33$ for sphalerite; Drovenik et al. 1970, 1980; Kuhlemann et al. 2001) and those obtained in this study ( $n=53$ for galena, $n=72$ for sphalerite). The distribution of these $\delta^{34} S$ values is summarized as histograms in Fig. 6 . The $\delta^{34} S$ values for galena samples range from -24.7 to $-1.4 \%$ o $(-10.7 \pm 5.9 \%, n=106)$, the distribution is unimodal but has a very pronounced skewness $(-0.73)$ with data spreading out to more negative ${ }^{34} S$ values. The mode is peaking at about $-7 \%$ and a smaller maximum appears near $-21 \%$. About half of the galena samples have $\delta^{34} S$ values $<-8 \%$ o (median $=-8.6 \%$ ). For all sphalerite 
samples, the $\delta^{34} S$ values range from -24.7 to $-1.5 \%$ $(-13.5 \pm 5.0 \%, n=104)$. The distribution has a fairly good skewness $(-0.07)$ meaning that the samples are welldistributed around the mean (even if slightly spread out to the left), with a major mode peak at $\sim-13 \%$. A lesser (statistically not significant) peak appears near $-20 \%$. These populations roughly match those defined by Schroll and Rantitsch (2005) in Bleiberg. The $\delta^{34} S$ values measured in this study indicate that sphalerite I $(-24.6$ to $-5.2 \%$, median $=-13.1 \%$ ), II $(-24.7$ to $-8.2 \%$, median $=$ $-13.6 \%$ ), and III ( -22.2 to $-6.9 \%$, median $=-14.4 \%$ ) has a similar isotopic composition throughout the orefield (Fig. 7). The latest generations of sphalerite (IV and V) have slightly higher $\delta^{34} S$ values than sphalerite I to III. The medians of the $\delta^{34} S$ values from the whole sample set show a small isotopic shift with paragenetic sequence (sphalerite I-sphalerite II, $\Delta^{34} \mathrm{~S}=-0.5 \%$ ) and (sphalerite II-sphalerite III, $\Delta^{34} S=-0.8 \%$ ). These $\delta^{34} S$ differences between sphalerite I, II, and III are up to $5.7 \%$ in individual hand specimens from conformable (e.g., sample ME-4; $\delta^{34} S$ values for sphalerite I, $-8.0 \%$; sphalerite II, $-10.0 \%$; sphalerite III, $-13.7 \%$; Fig. 8 ) or discordant orebodies (e.g., sample ME-4722, sphalerite I, $-10.6 \%$; sphalerite II, $-11.7 \%$; sphalerite III, $-13.4 \%$ ).

\section{Discussion}

The sulfur isotope compositions of the sulfides are controlled by different physicochemical parameters and processes during ore precipitation or replacement, including (1) isotopic composition of the fluid sulfur, (2) sulfur speciation, (3) fluid composition, (4) fluid temperature, $\mathrm{f}_{\mathrm{O} 2}$, and $\mathrm{pH}$, (5) changes in the metal-sulfur system due to mixing of different fluids, chemical exchanges between rock and fluid, extent of sulfide-precipitation, and open or closed nature (closeness) of the system (e.g., Ohmoto and Rye 1979; Ohmoto et al. 1985; Ohmoto and Goldhaber 1997). Kinetically driven isotopic effects between sulfides and fluid, accompanying (bacterially mediated) reduction and oxidation of sulfur compounds, and precipitation and dissolution of sulfur minerals can lead to situations of incomplete isotopic equilibrium in the fluid-sulfide system.

Assuming a single sulfur source, the variation of the sulfide $\delta^{34} S$ values could be explained by changes in temperature, $\mathrm{f}_{\mathrm{O} 2}$, and $\mathrm{pH}$. At Mežica, as in almost all lowtemperature carbonated-hosted mineralizations, mineralogical assemblages, the fluid inclusion temperature data, $\mathrm{pH}$ buffering by the carbonate host-rock, as well as the kinetic constraints on low-temperature exchange $\left(<160^{\circ} \mathrm{C}\right.$, Zeeh et al. 1998) between sulfide and sulfate indicate that the observed variations in the $\delta^{34} S$ values of the ore sulfides were not due to shifting of sulfate-sulfide equilibria in response to changes in the physicochemical environment of ore deposition $\left(\mathrm{f}_{\mathrm{O} 2}\right.$ or $\left.\mathrm{pH}\right)$. The Eh of the pore waters may vary with the presence of redox-sensitive elements/compounds, including $\mathrm{Fe}^{2+}$ and reactive organic molecules (see below). Thus, the speciation of sulfide $\left(\mathrm{S}^{2-}, \mathrm{HS}^{-}\right.$, and $\left.\mathrm{H}_{2} \mathrm{~S}\right)$ in MVT ore fluid may be significantly uniform at least at orebody scale, and the $\delta^{34} S$ variations are most probably due to the involvement of different sulfide sulfur sources.

\section{Sulfur source}

Triassic (Carnian) seawater sulfate was suggested as the source of sulfate sulfur in Bleiberg and other carbonatehosted $\mathrm{Pb}-\mathrm{Zn}$ deposits of the Eastern Alps, due to the similar isotopic composition of the measured evaporitic sulfates and those from Carnian seawater (Schroll et al. 1983; Schroll and Rantitsch 2005). Kuhlemann et al. (2001) measured $\delta^{34} S$ values of 12.2 and $17.3 \%$ in barite samples from Mežica (Luskačevo and Srednja Cona, respectively). These values bracket the values for Late Triassic (CarnianNorian) marine sulfates (15 to $17 \%$, Claypool et al. 1980; Cortecci et al. 1981) and are close to the mean composition of Carnian evaporites of the Eastern Alps (15.8 $\pm 0.4 \%$, Gotzinger, Lein, and Park 2001). Some of the sulfur could be derived from basement rocks, most likely from the Permian to Early to Middle Triassic (Scythian-Anisian) evaporites, which are locally preserved in the Drau Range (Kuhlemann et al. 2001).

Sulfate reduction generally causes isotopic fractionation of sulfur (e.g., Ohmoto and Goldhaber 1997). Sedimentary sulfide produced by biogenic reduction of seawater sulfate is typically enriched in ${ }^{32} S$ reflecting a large kinetic isotope effect compared with the parent sulfate $\left(\Delta_{\mathrm{H} 2 \mathrm{~S} \text {-sulfate }}\right.$ of up to $-75 \%$ ) and therefore has widely scattered $\delta^{34} S$ values (e.g., Ohmoto and Rye 1979). Detmers et al. (2001) studied the extent of sulfur isotope fractionation during dissimilatory sulfate reduction by pure cultures of 32 different sulfatereducing bacteria. All of the 32 bacteria discriminated against ${ }^{34} S$ during sulfate reduction. The completeoxidizing sulfate reducers fractionated sulfur between 15.0\% (Desulfosarcina variabilis) and 42.0\% (Desulfonema magnum), whereas the acetate-excreting incomplete oxidizers fractionated between 2.0\% (Desulfovibrio halophilus) and 18.7\% (Desulfonatrunun lacustre; Detmers et al. 2001).

Early diagenetic pyrite forms as a result of microbial processes in almost all systems (e.g., high- and low-sulfur systems in suboxic and anoxic environments) and may be replaced by base metals $(\mathrm{Zn}, \mathrm{Pb}$, and $\mathrm{Cu})$, forming less soluble sulfides. For sulfides formed during early diagenesis by bacterial reduction of coeval seawater sulfate in the sediments pore fluids it is expected: (1) a $\Delta_{\text {sulfide-sulfate }}=-45 \pm 20$, (2) a $\delta^{34} S$ range of less than 
Table 2 Sulfur isotope data of sulfides and sulfates from the Mežica ore deposit obtained in this study

\begin{tabular}{|c|c|c|c|c|c|c|c|}
\hline \multirow[t]{2}{*}{ Sample ID } & \multirow[t]{2}{*}{ Orebody/locality } & \multicolumn{2}{|c|}{ Coordinates $^{\mathrm{a}}$} & \multirow[t]{2}{*}{ Morph., ore phase ${ }^{b}$} & \multirow[t]{2}{*}{ Min. phase ${ }^{\mathrm{c}}$} & \multirow[t]{2}{*}{$\delta^{34} \mathrm{~S}(\%, \mathrm{VCDT})$} & \multirow[t]{2}{*}{ Color } \\
\hline & & $x$ & $y$ & & & & \\
\hline ME $1 / 1$ & Union, Vojn. rud. P. & 5150398 & 5488477 & Conf., I & gn & -8.2 & \\
\hline ME $1 / 2$ & Union, Vojn. rud. P. & 5150398 & 5488477 & Conf., I & gn & -8.9 & \\
\hline ME $1 / 3$ & Union, Vojn. rud. P. & 5150398 & 5488477 & Conf., I & gn & -7.7 & \\
\hline ME $1 / 4$ & Union, Vojn. rud. P. & 5150398 & 5488477 & Conf., I & sl-II & -16.2 & Brown \\
\hline ME $1 / 5$ & Union, Vojn. rud. P. & 5150398 & 5488477 & Conf., I & sl-II & -13.4 & Brown \\
\hline ME 1/6 & Union, Vojn. rud. P. & 5150398 & 5488477 & Conf., I & sl-I & -13.6 & Brown \\
\hline ME $1 / 7$ & Union, Vojn. rud. P. & 5150398 & 5488477 & Conf., I & sl-III & -7.0 & Green \\
\hline ME $2 / 1$ & Graben & 5148295 & 5489321 & Reef & sl-I & -12.5 & Brown \\
\hline $\operatorname{ME} 2 / 2$ & Graben & 5148295 & 5489321 & Reef & sl-I & -13.0 & Brown \\
\hline ME 3/1 & Graben & 5148295 & 5489321 & Conf., I & gn & -6.2 & \\
\hline ME $3 / 2$ & Graben & 5148295 & 5489321 & Conf., I & sl-I & -6.2 & Green-yellow \\
\hline $\operatorname{ME~} 3 / 3$ & Graben & 5148295 & 5489321 & Conf., I & sl-I & -5.7 & Green-yellow \\
\hline ME 3/4 & Graben & 5148295 & 5489321 & Conf., I & gn & -4.9 & \\
\hline ME $3 / 5$ & Graben & 5148295 & 5489321 & Conf., I & sl-I & -5.2 & Light yellow \\
\hline ME 4/1 & Moring & 5148798 & 5488473 & Karst infill & gn & -8.9 & \\
\hline ME $4 / 2$ & Moring & 5148798 & 5488473 & Karst infill & sl-III & -14.9 & Red brown \\
\hline $\operatorname{ME} 4 / 3$ & Moring & 5148798 & 5488473 & Karst infill & $\mathrm{mc}$ & -15.9 & \\
\hline ME 4/4 & Moring & 5148798 & 5488473 & Karst infill & sl-I & -8.0 & Green \\
\hline ME $4 / 5$ & Moring & 5148798 & 5488473 & Karst infill & sl-II & -10.1 & Dark green \\
\hline ME 4/6 & Moring & 5148798 & 5488473 & Karst infill & sl-III & -13.7 & Red brown \\
\hline ME 4/7 & Moring & 5148798 & 5488473 & Karst infill & $\mathrm{mc}$ & -15.0 & \\
\hline ME 4/8 & Moring & 5148798 & 5488473 & Karst infill & gn & -7.0 & \\
\hline ME 4/9 & Moring & 5148798 & 5488473 & Karst infill & sl-I & -8.1 & Dark green \\
\hline ME $4 / 10$ & Moring & 5148798 & 5488473 & Karst infill & gn & -3.2 & \\
\hline ME 5/1 & Srce & 5150647 & 5488927 & Conf., I & gn & -23.2 & \\
\hline ME $5 / 2$ & Srce & 5150647 & 5488927 & Conf., I & sl-I & -20.2 & $\begin{array}{l}\text { Brown-dark } \\
\text { brown }\end{array}$ \\
\hline ME $5 / 3$ & Srce & 5150647 & 5488927 & Conf., I & sl-I & -20.7 & Brown \\
\hline ME 5/4 & Srce & 5150647 & 5488927 & Conf., I & sl-I & -20.9 & Brown \\
\hline ME $5 / 5$ & Srce & 5150647 & 5488927 & Conf., I & gn & -23.0 & \\
\hline ME $6259 / 1$ & Barbara, adit Koroško & 5148798 & 5488473 & Disco., I & gn & -11.8 & \\
\hline ME $6259 / 2$ & Barbara, adit Koroško & 5148798 & 5488473 & Disco., I & sl-I & -24.6 & Gray brown \\
\hline ME $6259 / 3$ & Barbara, adit Koroöko & 5148798 & 5488473 & Disco., I & sl-II & -24.7 & Light brown \\
\hline ME $6259 / 4$ & Barbara, adit Koroško & 5148798 & 5488473 & Disco., I & py & -17.4 & Brown \\
\hline ME $11304 / 1$ & Moring & 5148798 & 5488473 & Disco.Disco., I & gn & -22.2 & \\
\hline ME $11304 / 2$ & Moring & 5148798 & 5488473 & Disco., I & sl-I & -20.9 & Light brown \\
\hline ME $11304 / 3$ & Moring & 5148798 & 5488473 & Disco., I & sl-II & -20.6 & Red brown \\
\hline ME $11304 / 4$ & Moring & 5148798 & 5488473 & Disco., I & sl-III & -18.8 & Yellow \\
\hline ME $11304 / 5$ & Moring & 5148798 & 5488473 & Disco., I & sl-IV & -19.9 & Light yellow \\
\hline ME $12104 / 1$ & Graben & 5148295 & 5489321 & Karst infill & gn & -5.9 & \\
\hline ME $12104 / 3$ & Graben & 5148295 & 5489321 & Karst infill & gn & -6.6 & \\
\hline ME $12104 / 5$ & Graben & 5148295 & 5489321 & Karst infill & gn & -8.6 & \\
\hline ME $4544 / 1$ & Igrčevo & 5150396 & 5468977 & Disco., I & gn & -16.6 & \\
\hline ME $4544 / 2$ & Igrčevo & 5150396 & 5468977 & Disco., I & sl-I & -19.4 & Yellow \\
\hline ME $4544 / 3$ & Igrčevo & 5150396 & 5468977 & Disco., I & sl-III & -11.5 & Light green \\
\hline ME $4544 / 4$ & Igrčevo & 5150396 & 5468977 & Disco., I & sl-IV & -13.1 & Light green \\
\hline ME $4544 / 5$ & Igrčevo & 5150396 & 5468977 & Disco., I & sl-II & -17.6 & Brown \\
\hline
\end{tabular}


Table 2 (continued)

\begin{tabular}{|c|c|c|c|c|c|c|c|}
\hline \multirow[t]{2}{*}{ Sample ID } & \multirow[t]{2}{*}{ Orebody/locality } & \multicolumn{2}{|c|}{ Coordinates $^{\mathrm{a}}$} & \multirow[t]{2}{*}{ Morph., ore phase ${ }^{b}$} & \multirow[t]{2}{*}{ Min. phase $\mathrm{e}^{\mathrm{c}}$} & \multirow[t]{2}{*}{$\delta^{34} \mathrm{~S}(\%, \mathrm{VCDT})$} & \multirow[t]{2}{*}{ Color } \\
\hline & & $x$ & $y$ & & & & \\
\hline ME $4722 / 1$ & Igrčevo & 5150396 & 5468977 & Disco., I & sl-III & -11.4 & Gray brown \\
\hline ME $4722 / 2$ & Igrčevo & 5150396 & 5468977 & Disco., I & sl-II & -13.4 & Yellow brown \\
\hline ME $4722 / 3$ & Igrčevo & 5150396 & 5468977 & Disco., I & sl-I & -10.6 & Green \\
\hline ME $4722 / 4$ & Igrčevo & 5150396 & 5468977 & Disco., I & gn & -6.7 & \\
\hline ME $4722 / 5$ & Igrčevo & 5150396 & 5468977 & Disco., I & sl-II & -11.7 & Yellow brown \\
\hline ME $10974 / 1$ & Barbara & 5150997 & 5488779 & Conf., II & gn & -7.2 & \\
\hline ME $10974 / 2$ & Barbara & 5150997 & 5488779 & Conf., II & $\mathrm{mc}$ & -18.7 & \\
\hline ME $10974 / 3$ & Barbara & 5150997 & 5488779 & Conf., II & $\mathrm{mc}$ & -19.0 & \\
\hline ME $10974 / 4$ & Barbara & 5150997 & 5488779 & Conf., II & sl-I & -11.6 & Brown \\
\hline ME $10974 / 5$ & Barbara & 5150997 & 5488779 & Conf., II & sl-II & -12.2 & Red brown \\
\hline ME 10974/6 & Barbara & 5150997 & 5488779 & Conf., II & $\mathrm{mc}$ & -18.1 & \\
\hline ME 10974/7 & Barbara & 5150997 & 5488779 & Conf., II & sl-I & -10.0 & Brown \\
\hline ME $10974 / 8$ & Barbara & 5150997 & 5488779 & Conf., II & sl-II & -12.6 & Red brown \\
\hline ME 10974/9 & Barbara & 5150997 & 5488779 & Conf., II & $\mathrm{mc}$ & -12.4 & \\
\hline ME $10974 / 10$ & Barbara & 5150997 & 5488779 & Conf., II & sl-III & -8.8 & Green brown \\
\hline ME 6/1 & Luskačevo & 5150502 & 5487027 & Disco., II & gn & -15.0 & \\
\hline ME $6 / 2$ & Luskačevo & 5150502 & 5487027 & Disco., II & sl-I & -13.1 & Light brown \\
\hline ME $6 / 3$ & Luskačevo & 5150502 & 5487027 & Disco., II & $\mathrm{mc}$ & -15.4 & \\
\hline ME 6/4 & Luskačevo & 5150502 & 5487027 & Disco., II & sl-I & -13.1 & Light brown \\
\hline ME $6 / 5$ & Luskačevo & 5150502 & 5487027 & Disco., II & sl-I & -11.9 & Gray brown \\
\hline ME 8/1 & Luskačevo & 5150502 & 5487027 & Disco., II & gn & -7.3 & \\
\hline ME $8 / 2$ & Luskačevo & 5150502 & 5487027 & Disco., II & sl-III & -14.7 & Light brown \\
\hline ME $8 / 3$ & Luskačevo & 5150502 & 5487027 & Disco., II & gn & -6.8 & \\
\hline ME $8 / 4$ & Luskačevo & 5150502 & 5487027 & Disco., II & $\mathrm{mc}$ & -17.9 & \\
\hline ME $8 / 5$ & Luskačevo & 5150502 & 5487027 & Disco., II & sl-II & -8.2 & Gray brown \\
\hline ME $8 / 6$ & Luskačevo & 5150502 & 5487027 & Disco., II & sl-III & -15.6 & Gray brown \\
\hline ME 5047/1 & Navršnik-Barget & 5148251 & 5487321 & Disco., I & gn & -11.5 & \\
\hline ME 5047/2 & Navršnik-Barget & 5148251 & 5487321 & Disco., I & gn & -8.3 & \\
\hline ME 5060/1 & Fridrih & 5151147 & 5488780 & Disco. & gn & -17.2 & \\
\hline ME 5060/2 & Fridrih & 5151147 & 5488780 & Disco. & sl-I & -14.7 & Brown \\
\hline ME 5060/3 & Fridrih & 5151147 & 5488780 & Disco. & gn & -16.4 & \\
\hline ME 5060/4 & Fridrih & 5151147 & 5488780 & Disco. & sl-I & -13.2 & Gray brown \\
\hline ME 5060/5 & Fridrih & 5151147 & 5488780 & Disco. & sl-II & -13.8 & Green \\
\hline ME 5605/1 & Eerjav-Graben & 5148295 & 5489321 & Disco., II & gn & -12.4 & \\
\hline ME 5605/2 & Eerjav-graben & 5148295 & 5489321 & Disco., II & sl-II & -10.5 & Dark yellow \\
\hline ME $5605 / 3$ & Eerjav-Graben & 5148295 & 5489321 & Disco., II & sl-I & -7.2 & Dark green \\
\hline ME 5605/4 & Eerjav-Graben & 5148295 & 5489321 & Disco., II & gn & -13.4 & \\
\hline ME $5605 / 5$ & Eerjav-Graben & 5148295 & 5489321 & Disco., II & $\mathrm{mc}$ & -20.0 & \\
\hline ME 9518/1 & Navrönik-Barget & 5148251 & 5487321 & & gn & -1.4 & \\
\hline ME $12497 / 1$ & Triurno & 5150225 & 5487626 & Disco. & gn & -2.3 & \\
\hline ME $12497 / 2$ & Triurno & 5150225 & 5487626 & Disco. & sl-I & -15.9 & Brown \\
\hline ME $12497 / 3$ & Triurno & 5150225 & 5487626 & Disco. & sl-II & -16.2 & Orange brown \\
\hline ME $12497 / 4$ & Triurno & 5150225 & 5487626 & Disco. & sl-III & -14.4 & Orange brown \\
\hline ME $12497 / 5$ & Triurno & 5150225 & 5487626 & Disco. & sl-IV & -13.1 & Red \\
\hline ME $12497 / 6$ & Triurno & 5150225 & 5487626 & Disco. & sl-V & -1.5 & Gray brown \\
\hline ME $12497 / 7$ & Triurno & 5150225 & 5487626 & Disco. & sl-V & -12.3 & Red \\
\hline ME $12497 / 8$ & Triurno & 5150225 & 5487626 & Disco. & sl-V & -5.1 & Light brown \\
\hline
\end{tabular}


Table 2 (continued)

\begin{tabular}{|c|c|c|c|c|c|c|c|}
\hline \multirow[t]{2}{*}{ Sample ID } & \multirow[t]{2}{*}{ Orebody/locality } & \multicolumn{2}{|c|}{ Coordinates $^{\mathrm{a}}$} & \multirow[t]{2}{*}{ Morph., ore phase ${ }^{b}$} & \multirow[t]{2}{*}{ Min. phase ${ }^{\mathrm{c}}$} & \multirow[t]{2}{*}{$\delta^{34} \mathrm{~S}(\%, \mathrm{VCDT})$} & \multirow[t]{2}{*}{ Color } \\
\hline & & $x$ & $y$ & & & & \\
\hline ME $12497 / 9$ & Triurno & 5150225 & 5487626 & Disco. & sl-V & -10.5 & Brown \\
\hline ME $12493 / 1$ & Graben & 5148295 & 5489321 & Karst infill & gn & -5.1 & \\
\hline ME $12493 / 2$ & Graben & 5148295 & 5489321 & Karst infill & gn & -3.3 & \\
\hline ME $12493 / 4$ & Graben & 5148295 & 5489321 & Karst infill & gn & -6.8 & \\
\hline ME $12575 / 1$ & Srednja cona & 5148849 & 5487872 & Conf. & gn & -5.0 & \\
\hline ME $12575 / 2$ & Srednja cona & 5148849 & 5487872 & Conf. & gn & -3.2 & \\
\hline ME $12575 / 3$ & Srednja cona & 5148849 & 5487872 & Conf. & gr & -2.3 & Green \\
\hline ME $12110 / 1$ & Graben & 5148295 & 5489321 & Karst & gn & -6.2 & \\
\hline ME $12110 / 3$ & Graben & 5148295 & 5489321 & Karst & gn & -8.2 & \\
\hline ME $12109 / 1$ & Graben & 5148295 & 5489321 & Disco., II & sl-I & -5.3 & Gray yellow \\
\hline ME $12109 / 2$ & Graben & 5148295 & 5489321 & Disco., II & gn & -7.0 & \\
\hline ME $12109 / 3$ & Graben & 5148295 & 5489321 & Disco., II & sl-I & -5.2 & Gray \\
\hline ME $12109 / 4$ & Graben & 5148295 & 5489321 & Disco., II & sl-II & -12.2 & Red brown \\
\hline ME $11071 / 1$ & Navrönik-Barget & 5148251 & 5487321 & Disco., II & gn & -14.5 & \\
\hline ME 5050/1 & Fridrih & 5151147 & 5488780 & Conf.. & gn & -6.5 & \\
\hline ME 5050/2 & Fridrih & 5151147 & 5488780 & Conf. & gn & -16.5 & \\
\hline ME 5050/3 & Fridrih & 5151147 & 5488780 & Conf. & sl-I & -19.7 & Yellow \\
\hline ME 5050/4 & Fridrih & 5151147 & 5488780 & Conf. & sl-II & -19.1 & Light brown \\
\hline ME 5050/5 & Fridrih & 5151147 & 5488780 & Conf. & sl-III & -22.2 & Dark brown \\
\hline ME 5050/6 & Fridrih & 5151147 & 5488780 & Conf. & sl-IV & -9.6 & Green \\
\hline ME 13325 & Moring & 5148798 & 5488473 & Disco., II & gr & -15.0 & Yellow \\
\hline ME 4544/A & Igrčevo & 5150396 & 5468977 & Disco., II & gn & -19.0 & \\
\hline ME 4544/A & Igrčevo & 5150396 & 5468977 & Disco., II & sl-I & -21.2 & \\
\hline ME 4544/A & Igrčevo & 5150396 & 5468977 & Disco., II & sl-II & -17.5 & Greenish \\
\hline ME 4544/B & Igrčevo & 5150396 & 5468977 & Disco., II & gn & -20.8 & \\
\hline ME 4544/B & Igrčevo & 5150396 & 5468977 & Disco., II & sl-I & -21.0 & \\
\hline ME 4544/B & Igrčevo & 5150396 & 5468977 & Disco., II & sl-II & -15.4 & Greenish \\
\hline ME 5605 & Graben-Žerjav & 5148295 & 5489321 & & $\mathrm{mc}$ & -18.1 & \\
\hline ME 9518 & Navršnik-Barget & 5150398 & 5488477 & Disco. & gn & -6.6 & \\
\hline ME 4714 & Union, Vojn. rud. P. & 5148295 & 5489321 & Disco. & gn & -7.6 & \\
\hline ME 9 & Graben & 5151147 & 5488780 & Conf. & py & -17.3 & \\
\hline ME 5048 & Fridrih & 5151147 & 5488780 & Conf. & gn & -17.0 & \\
\hline ME 5044 & Fridrih & 5150396 & 5468977 & Conf. & gn & -17.1 & \\
\hline ME 7 & Igrčevo & 5150396 & 5468977 & Conf. & gn & -17.6 & \\
\hline ME 7 & Igrčevo & 5150398 & 5488477 & Conf. & sl-I & -13.4 & \\
\hline ME 10/a & Helena & 5150997 & 5488779 & & py & -27.3 & \\
\hline ME 10/b & Helena & 5150997 & 5488779 & & py & -29.0 & \\
\hline ME 6118 & Moring & 5148798 & 5488473 & & $\mathrm{gp}$ & -16.3 & \\
\hline ME 11 & Luskačevo & 5150502 & 5487027 & & gp & -19.5 & \\
\hline ME 9812 & & & & & gp & -16.1 & \\
\hline ME 11057 & Graben & 5148295 & 5489321 & & py & -15.4 & \\
\hline ME 6119 & Moring & 5148798 & 5488473 & & gp & -17.8 & \\
\hline ME 13253 & $\begin{array}{l}\text { Centralna jama-Srednja } \\
\text { cona }\end{array}$ & 5148849 & 5487872 & Conf. & sl-I & -8.2 & \\
\hline ME 13253 & $\begin{array}{l}\text { Centralna jama-Srednja } \\
\text { cona }\end{array}$ & 5148849 & 5487872 & Conf. & gn & -11.1 & \\
\hline ME 13155 & Naverönik-Barget & 5148251 & 5487321 & Conf. & gn & -10.7 & \\
\hline ME 13155 & Naverönik -Barget & 5148251 & 5487321 & & gr & -19.2 & \\
\hline
\end{tabular}


Table 2 (continued)

\begin{tabular}{|c|c|c|c|c|c|c|c|}
\hline \multirow[t]{2}{*}{ Sample ID } & \multirow[t]{2}{*}{ Orebody/locality } & \multicolumn{2}{|c|}{ Coordinates $^{\mathrm{a}}$} & \multirow[t]{2}{*}{ Morph., ore phase ${ }^{b}$} & \multirow[t]{2}{*}{ Min. phase ${ }^{c}$} & \multirow[t]{2}{*}{$\delta^{34} \mathrm{~S}(\%, \mathrm{VCDT})$} & \multirow[t]{2}{*}{ Color } \\
\hline & & $x$ & $y$ & & & & \\
\hline ME 12576 & Moring & 5148798 & 5488473 & & gr & -13.5 & \\
\hline ME 12268 & Union 300 & 5150398 & 5488477 & & gr & -11.0 & \\
\hline ME $100 / 3$ & Luskačevo & 5150502 & 5487027 & & sl-III & -13.1 & Yellowish \\
\hline ME 200/7 & Luskačevo & 5150502 & 5487027 & & sl-III & -14.5 & Brown \\
\hline ME 200/8 & Luskačevo & 5150502 & 5487027 & & sl-III & -14.7 & Yellow-brown \\
\hline ME 13253 & $\begin{array}{l}\text { Srednja cona-centralna } \\
\text { jama }\end{array}$ & 5148849 & 5487872 & & gr & -7.8 & \\
\hline ME 300/1 & Luskačevo & 5150502 & 5487027 & & gn & -20.8 & \\
\hline ME 300/2 & Luskačevo & 5150502 & 5487027 & & gn & -15.3 & \\
\hline ME 300/4 & Luskačevo & 5150502 & 5487027 & & gn & -16.2 & \\
\hline ME 300/5 & Luskačevo & 5150502 & 5487027 & & gn & -17.6 & \\
\hline
\end{tabular}

${ }^{a}$ Coordinates according to the Gauss-Krüger International Geographical System. They were recalculated from the Mežica mine local coordinates. When exact location of the ore sample is unknown, the coordinates correspond to the center of the orebody

${ }^{\mathrm{b}}$ Morphology of orebody: Conf. concordant to bedding (conformable), Disco. discordant to bedding (disconformable); Ore phase I or II

${ }^{\mathrm{c}}$ Minerals analyzed: $b a$ barite, $g p$ gypsum, $s l$ sphalerite (generations I, II, and III), gn galena, $m c$ marcasite, $g c$ greenockite

$10 \%$ among sulfides occurring on a hand specimen scale, and (3) less than $\pm 20 \%$ o $\delta^{34} S$ difference among those occurring within a lithologically homogeneous orebody, and (4) sulfur isotopic disequilibrium between the coexisting sulfides (Ohmoto et al. 1985).

If isotopic equilibrium is established among the coexisting sulfide minerals, the $\delta^{34} S$ values should decrease in the order: $\delta^{34} S_{\text {pyrite }}>\delta^{34} S_{\text {sphalerite }}>\delta^{34} S_{\text {chalcopyrite }}>\delta^{34} S_{\text {galena }}$ (e.g., Ohmoto and Goldhaber 1997). High-temperature, inorganic reduction of sulfate may also cause fractionation (Ohmoto and Rye 1979). Thermochemical $\left(>80^{\circ} \mathrm{C}\right)$ reduction of sulfates by organic compounds involves little or no isotopic fractionation between sulfate and $\mathrm{H}_{2} \mathrm{~S}$

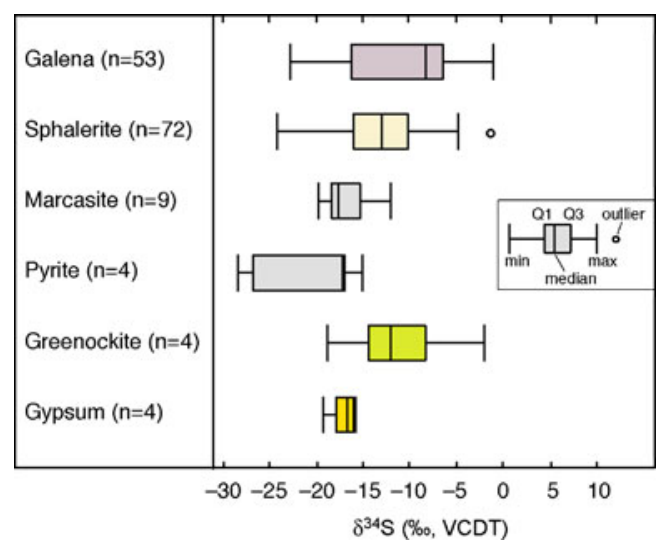

Fig. 5 Box plot of $\delta^{34} \mathrm{~S}$ values for the sulfur minerals from Mežica deposit obtained in this study, displaying the ranges, 25th (first quartile, Q1) and 75th (third quartile, Q3) percentiles, median, and outliers compared with the fractionation expected from equilibrium fractionation factors (Ohmoto et al. 1985; Machel et al. $1995)$. Generally, the $\Delta_{\text {sulfide-sulfate }}$ values are $\sim-5 \%$ for local generation of $\mathrm{H}_{2} \mathrm{~S}$ in a shallow environment and range between 0 and $-10 \%$ for $\mathrm{H}_{2} \mathrm{~S}$ formed at depth and transported to the ore site (Ohmoto et al. 1985). Nonbacterial sulfate reduction by organic matter or by inorganic reductants (e.g., $\mathrm{Fe}^{2+}$ ) does not operate efficiently at temperatures below $200^{\circ} \mathrm{C}$ (e.g., Ohmoto et al. 1985).

The pore-water $\mathrm{H}_{2} \mathrm{~S}$ produced by bacterial reduction of seawater sulfate or evaporite sulfate during early diagenesis is precipitated as sulfide or is incorporated into recently deposited metabolizable organic matter produced by decay of a bacterial or algal mat (e.g., Werne et al. 2003). The precipitation of sulfides is strongly controlled by the availability of reactive $\mathrm{Fe}^{2+}$. The fossil biomass (kerogen, bitumen, and petroleum) in a marine-carbonate type depositional environment with limited availability of $\mathrm{Fe}$ may contain a high amount of organically bound sulfur. Reduced sulfur species such as hydrogen sulfides $\left(\mathrm{H}_{2} \mathrm{~S}\right)$, elemental sulfur $\left(\mathrm{S}_{8}\right)$, and polysulfides $\left(\mathrm{S}_{\mathrm{n}}{ }^{2-}\right)$ are the major sulfur donors in reactions with organic molecules (e.g., Orr 1978).

The Mežica sulfur isotope data suggest that the sulfides mostly originated from biogenic reduction of Late Triassic seawater sulfate and evaporite sulfate. The ore sulfides (galena, sphalerite, marcasite, pyrite, and greenockite) cover a $28 \%$ range of negative values ( -29.4 to $-1.4 \%,-12.8 \pm 5.8 \%, n=235$, data from Drovenik et al. 1980; Kuhlemann et al. 2001, and this study). The modes in the distributions of the sulfur isotope 
Fig. 6 Frequency distribution of $\delta^{34} \mathrm{~S}$ values for galena (a) and sphalerite (b) from Mežica deposit. Data from Drovenik et al. (1970, 1980), Kuhlemann et al. (2001) and this study. The data for galena are not following a normal distribution ( $p$ value of $0.0000003)$. The distribution of the $\delta^{34} \mathrm{~S}$ values for sphalerite follows a normal law at a significance level (alpha level) of 0.05 (with a $p$ value of $0.1519)$

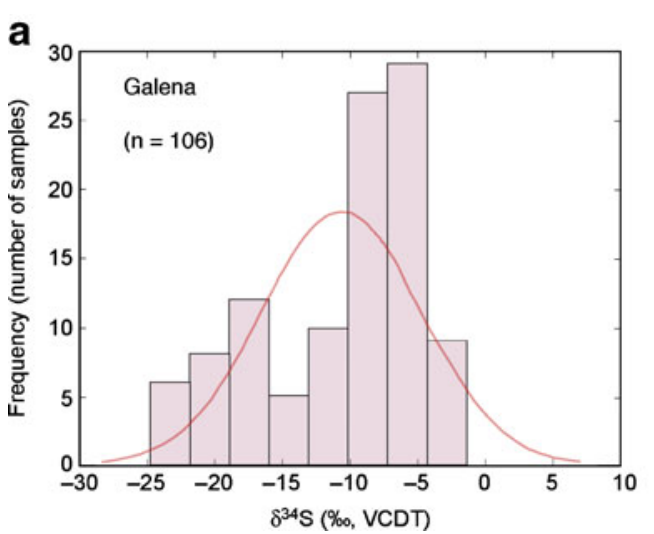

composition of galena and sphalerite (Fig. 5) roughly bracket the $\delta^{34} S$-populations defined by Schroll and Ranitsch (Schroll and Rantitsch 2005) at Bleiberg. The observed ${ }^{34}$ S-enrichment order $\delta^{34} S_{\text {pyrite }}<\delta^{34} S_{\text {sphalerite }}$ $<\delta^{34} S_{\text {galena }}$ (Fig. 5) is reversed from that expected for thermodynamic equilibrium, indicating that these coexisting sulfides formed at isotopic disequilibrium, most probably at different times from different solutions. The occurrence of bacterial activity at the site of mineralization at Topla (i.e., bacterial mats as proposed by Spangenberg and Herlec 2006) and other deposits of the Drau Range is confirmed by the presence of bacterial relics (Kucha et al. 2001, 2005). A recent inorganic and organic geochemical study of ore samples from the Luskačevo and Union localities (Spangenberg and Herlec 2006) provides further support for the biogenic reduction of sulfate as the main sulfide source to Mežica sulfides. The concentration of redox-sensitive elements (i.e., $\mathrm{Fe}, \mathrm{Mn}, \mathrm{U}$, and $\mathrm{Ce}$ ) and total REE increase with mineralization time reflect an anoxic depositional environment of the Ladinian mineralized carbonates and reducing conditions at the ore site. In such a reducing environment, sulfur isotope fractionation due to changes in $\mathrm{f}_{\mathrm{O} 2}$ is negligible, and thus the $\delta^{34} S$-variations of

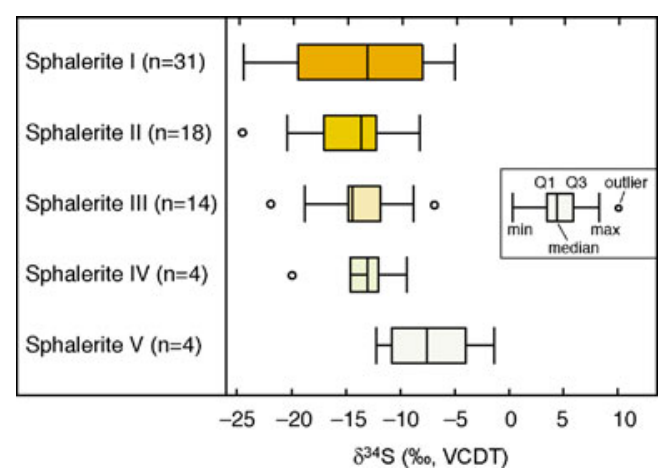

Fig. 7 Box plot of $\delta^{34} \mathrm{~S}$ values for sphalerite generations from Mežica deposit, displaying the ranges, 25th (first quartile, Q1) and 75th (third quartile, Q3) percentiles, median, and outliers

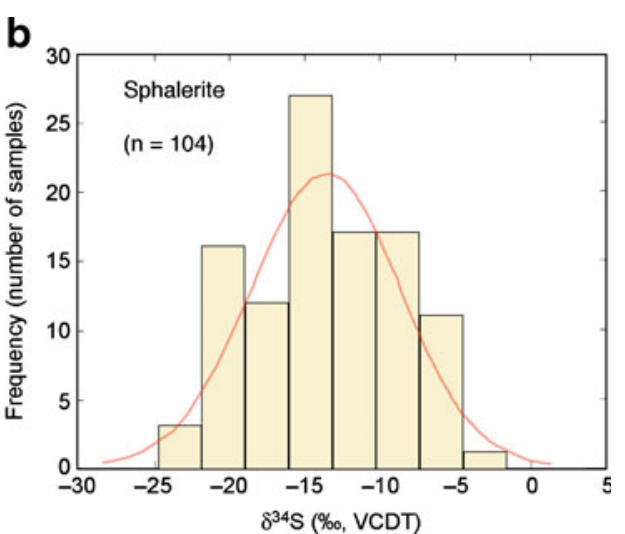

the sulfides reflect mostly the changes in the composition of the sulfur source. The results of the organic geochemical study (Spangenberg et al. 2001; Spangenberg and Herlec 2006) show that: (1) all the samples contain high amounts of elemental sulfur (as $\mathrm{S}_{8}$ ) in the extracted bitumen, (2) the $\mathrm{Pb}$ and $\mathrm{Zn}$ ore samples contain high amounts of squalane $\left(\mathrm{a}_{30}\right.$ irregular isoprenoid), which has been identified in methanogenic sulfate-reducing bacteria and in strongly reducing environments (e.g., de Wit et al. 1994; Chaler et al. 2005), (3) the ore samples contain also relatively higher amounts of hopanes (biomarker of prokaryotes: bacteria and Archaea) than of steranes (biomarker of eukaryotes, including algae, fungi, and higher organisms), and the hopane/sterane concentration ratios are roughly correlated with the sum of $\mathrm{Pb}$ and $\mathrm{Zn}$ concentrations, (4) all the samples have high concentration of sulfur-aromatic compounds, including thiophenes, thiolanes, and unidentified sulfur compounds. The relative concentration of these compounds is higher in mineralized samples than in barren host rocks, most likely reflecting different chemical and thermal degradation processes at the ore site. The organic geochemical results suggest that pore-water $\mathrm{H}_{2} \mathrm{~S}$ was mainly incorporated into organic matter, most probably by sulfurization of carbohydrates in the humic fractions (e.g., van Dongen et al. 2003; Amrani and Aizenshtat 2004). Kuhlemann et al. (2001) proposed that at least part of the reduced sulfur from the first ore stage with $\delta^{34} \mathrm{~S}_{\text {sulfide }}$ values between -11 and $-23 \%$ was formed by abiogenic reduction of Late Triassic seawater sulfate of $+15 \%$ and equilibrium fractionation at $150^{\circ} \mathrm{C}$ to $200^{\circ} \mathrm{C}$ of -35 to $-30 \%$. However, this is unlikely, given the kinetic limitations to sulfate-sulfide reactions at the low temperature of ore formation at Mežica (e.g., Ohmoto and Lasaga 1982). We propose that thermochemical sulfate reduction by organic compounds produced isotopically heavy sulfides, as a result of a small sulfate- $\mathrm{H}_{2} \mathrm{~S}$ isotopic fractionation, contributing isotopically heavier $\mathrm{H}_{2} \mathrm{~S}$ to the ore fluid at Mežica. The progressively more negative $\delta^{34} \mathrm{~S}$ values along the sphalerite generations (Fig. 8, Table 2) are consistent with (1) mixing of different $\mathrm{H}_{2} \mathrm{~S}$ sources, (2) 
a decreasing contribution of isotopically heavier sulfide sulfur probably from (regional) thermochemical reduction of evaporite sulfate, and (3) a relatively more substantial contribution from the local reservoir of isotopicaly light sulfur (i.e., sedimentary biogenic pyrite, organo-sulfur compounds).

The new sulfur isotope data, combined with the inorganic and organic geochemical information of the $\mathrm{Pb}-\mathrm{Zn}$ mineralization at Mežica-Topla area, discussed in Spangenberg and Herlec (2006), suggest that the sulfide species $\left(\mathrm{S}^{2-}, \mathrm{HS}^{-}\right.$, and $\left.\mathrm{H}_{2} \mathrm{~S}\right)$ in the ore fluid originated from different processes involving organic compounds. These include: (1) bacterially mediated reduction of dissolved sulfate (seawater sulfate or evaporite sulfate) by reaction with organic compounds in an anoxic environment (bacterial mats); (2) cracking of organic compounds containing organically bound sulfur (with C$\mathrm{S}$ bonds) during maturation of the indigenous fossil biomass (kerogen, bitumen); (3) reduction of molecular sulfur $\left(\mathrm{S}_{8}\right)$ in the local/indigenous bitumen staining the host rocks; (4) reaction with indigenous organo-sulfur compounds with a primary C-skeleton of biologic origin (e.g., hopanoids, steroids, and isoprenoids containing thiophene rings); or (5) the ore fluids introduced labile organic sulfur (from early diagenetic carbohydrates and lipids) into the ore site. Slow and gradual release of sulfur during thermal and chemical transformations of these labile organic sulfur compounds during prograde diagenesis and post-depositional alteration may have contributed to accumulation of ore sulfides (e.g., Rospondek et al. 1994). Most of the early diagenetic pyrite could be later replaced by $\mathrm{Zn}$ and $\mathrm{Pb}$ sulfides. The fluid inclusion studies indicate that MVT mineralization in conformable orebodies originated from hot $\left(122^{\circ} \mathrm{C}\right.$ to $159^{\circ} \mathrm{C}$, Drovenik
1983; Zeeh et al. 1998) fluids during deep burial diagenesis, making unlikely the formation of $\mathrm{Pb}-\mathrm{Zn}$ ores along with pyrite directly via involvement of bacterial sulfate reduction at the depositional site.

In summary, almost all the reduced sulfur species in the carbonate rocks of the Mežica-Topla area derived from reactions with organic compounds on different sites and different times during evolution of the carbonate platform. The main sources of reduced sulfur $\left(\mathrm{H}_{2} \mathrm{~S}\right)$ for Mežica $\mathrm{Pb}$ and $\mathrm{Zn}$ sulfides were the hydrolysis of biogenic pyrite and alteration/breakdown of organo-sulfur compounds. The strong local variations of the sulfur isotope compositions indicate local control of reduction processes. Some variation of the $\delta^{34} \mathrm{~S}$ values is attributed to primary isotopic heterogeneities in the biogenic $\mathrm{H}_{2} \mathrm{~S}$ reservoir due to inherent variability of bacterial sulfate reduction, including metabolic recycling in a locally partially closed system, and variable contributions of $\mathrm{H}_{2} \mathrm{~S}$ from different sources (pyrite, organosulfur compounds).

Comparison of the sulfur isotope patterns of conformable vs. discordant ore

The sulfur isotope compositions of the $\mathrm{Pb}$ and $\mathrm{Zn}$ sulfides vary as a function of the mineralization stage. Galena of ore stages I and II in discordant orebodies is depleted in ${ }^{34} \mathrm{~S}$ on average by $6.4 \%$ compared with the equivalent sulfide phase in conformable orebodies (Fig. 9). A similar trend is observed in sphalerite I and II for the first ore phase (Fig. 10). The origin of isotopically light $\mathrm{H}_{2} \mathrm{~S}$ at the discordant ore depositional site may be due to: (1) introduction of light $\mathrm{H}_{2} \mathrm{~S}$ from preferential leaching of ${ }^{34}$ S-depleted conformable sulfides; (2) bacterial reworking of remobilized conformable sulfides; (3) a more important

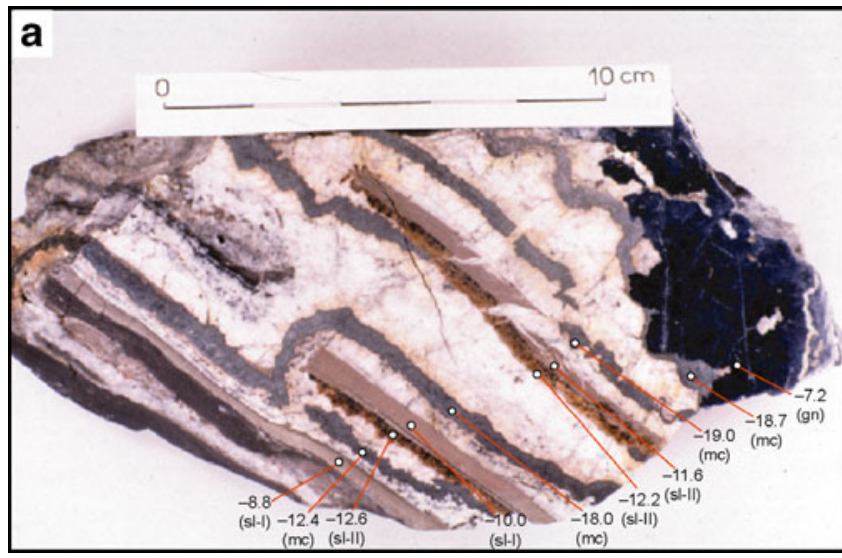

Fig. 8 Sulfur isotope composition of sphalerite, galena, and marcasite in hand-specimens of Mežica ore. a Deformed and recrystallized zebra ore, sample ME 10974/5, Barbara orebody. b Sphalerite generation I,

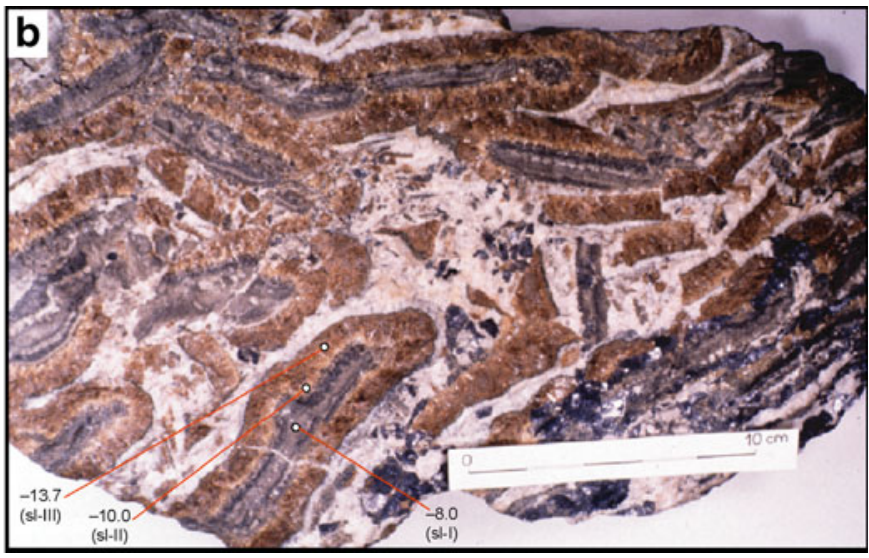

II, and III in a breccia ore, sample ME-4, Moring orebody ( $s l$ sphalerite, $g n$ galena, and $m c$ marcasite) 


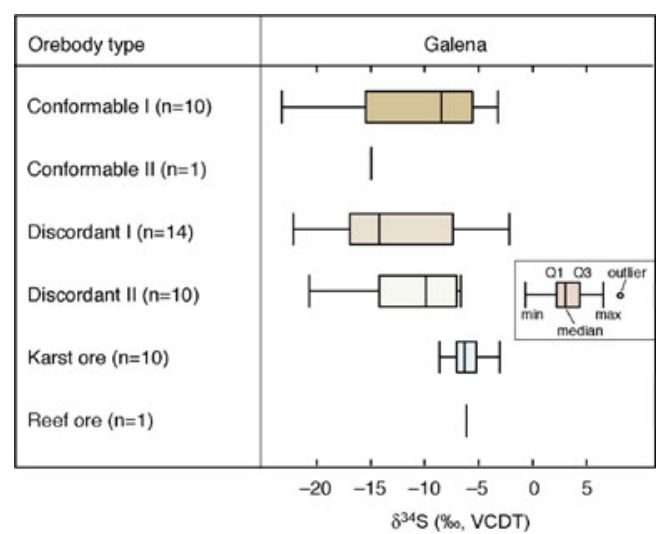

Fig. 9 Box plot of $\delta^{34} \mathrm{~S}$ values for galena from the main ore stages in different types of orebodies (as defined by Drovenik et al. 1980) in Mežica deposit

contribution of isotopically light sedimentary sulfur from degradation of biogenic pyrite or organo-sulfur compounds (Ohmoto and Goldhaber 1997) in the precipitation of stage II sulfides. Additionally, sulfate-sulfide exchange reactions, triggered by changes in temperature, $\mathrm{pH}$, and $\mathrm{f}_{\mathrm{O} 2}$ of the mineralizing fluid in the fault zones, causing evolution of the oxidation state of the sulfur reservoir through time, may induce further $\delta^{34} \mathrm{~S}$ differences. Drovenik (1983) found that the $\delta^{34} \mathrm{~S}$ values of galena in discordant orebodies are less scattered than those from the conformable ones. Ore stage II galena from two closely located discordant orebodies has distinct isotopic composition (Union section: -5.4 to 10.8\%o; Stari Fridrih section: -19.7 to $-14.8 \%$ ), indicating that the sulfur remobilization was in general short (decimeterto meter-scale) and did not exceed hundreds of meters (Drovenik 1983). Our data do not show such homogenization of the $\delta^{34} \mathrm{~S}$ values at the orefield scale. Stage II galena in discordant orebodies is enriched in ${ }^{34} \mathrm{~S}$ compared with the stage I sulfide. This may reflect that stage I ore in discordant orebodies was formed from leaching of the ${ }^{34} \mathrm{~S}$-depleted sulfur species of the conformable mineralization. The ore stage II sulfides precipitated from the remnant $\left({ }^{34} \mathrm{~S}\right.$-enriched) sulfur pool. The $\delta^{34} \mathrm{~S}$ values of primary Ladinian to Carnian karst and reef-bound ore are in the range of conformable sulfides (Figs. 9 and 10).

\section{Conclusions}

The $\delta^{34} \mathrm{~S}$ values for sulfide minerals from Mežica cover a wide range of negative values $(-29.0 \%$ to $-1.4 \%, n=236)$ for the entire paragenetic sequence. This confirms the previously reported wide regional and hand specimenscale variations of negative $\delta^{34} \mathrm{~S}$ values of the sulfide minerals in the low-temperature $\mathrm{Pb}-\mathrm{Zn}$ deposits of the Drau Range. The $\delta^{34} \mathrm{~S}$ values are arranged in the order $\delta^{34} \mathrm{~S}_{\text {pyrite }}<\delta^{34} \mathrm{~S}_{\text {sphalerite }}<\delta^{34} \mathrm{~S}_{\text {galena }}$ indicating isotopically heterogeneous $\mathrm{H}_{2} \mathrm{~S}$ in the ore-forming fluids and that precipitation of the sulfides occured at thermodynamic disequilibrium. This indicates that the $\mathrm{H}_{2} \mathrm{~S}$ primarily originated from local bacterial reduction of evaporite sulfate and possibly seawater sulfate. There is a correlation between the sulfur isotope composition of sphalerite and galena and the paragenetic stage of ore deposition: (1) for sphalerite, the $\delta^{34} \mathrm{~S}$ values increase from earlier to latestage generations, (2) and decrease from conformable to discordant mineralization of the same ore stage, and (3) galena displays similar $\delta^{34} \mathrm{~S}$ variations in conformable and discordant ore. The data set best supports the assumption that the sulfur in discordant orebodies originates from selective leaching of ${ }^{34} \mathrm{~S}$-depleted sulfide species from conformable orebodies although a contribution of isotopically light biogenic $\mathrm{H}_{2} \mathrm{~S}$ cannot be excluded. The more negative $\delta^{34} \mathrm{~S}$ values along the sphalerite generations in a hand specimen ore samples are consistent with an increasing contribution from the reservoir of isotopicaly light sulfur (i.e., sedimentary biogenic pyrite, organosulfur compounds). The geological, textural, and the new $\delta^{34} \mathrm{~S}$ data are consistent with the previously proposed
Fig. 10 Box plot of $\delta^{34} \mathrm{~S}$ values for sphalerite I and II from the main ore stages in different types of orebodies (defined by Drovenik et al. 1980) in Mežica deposit

\section{a}

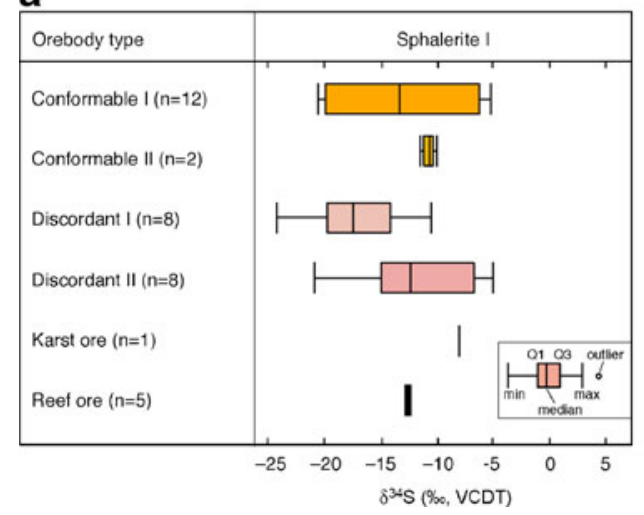

b

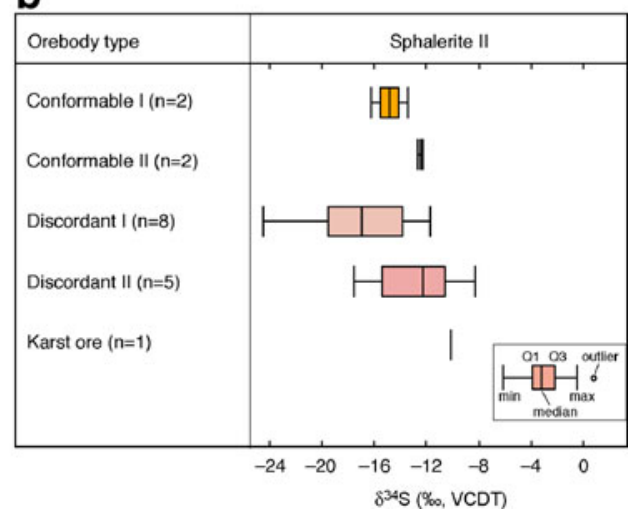


genetic model of Mežica ore as being an MVT deposit, involving (1) bacterial reduction of seawater and evaporite sulfate as the main source of $\mathrm{H}_{2} \mathrm{~S}$, and (2) mixing of regionally extensive metal-rich fluids and the local biogenic sulfide sulfur.

Acknowledgements We thank the management of Rudnik Mežica Mining Company and in particular Suzana Fajmut-Štrucl and Miha Pungartnik for help during field work. Eric Verrecchia helped in statistical analyses. Matjaž Učakar has redrawn the geological map. Jorge Spangenberg would like to thank Barbara Čenčur-Curk, for her discussion and logistical help in the early stage of the project. This study was supported by the Swiss National Science Foundation (grants no. 2100-059198 and 2100-100401) and the University of Lausanne. Constructive review and suggestions by two MD reviewers helped to improve the manuscript. Editorial support from Bernd Lehmann is much appreciated.

\section{References}

Amrani A, Aizenshtat Z (2004) Mechanisms of sulfur introduction chemically controlled: $\delta^{34} \mathrm{~S}$ - imprint. Org Geochem 35:1319-1336

Anderson GM (2008) The mixing hypothesis and the origin of Mississippi Valley-type ore deposits. Econ Geol 103:1683-1690

Anderson GM, Thom J (2008) The role of thermochemical sulfate reduction in the origin of Mississippi Valley-type deposits. II. Carbonate-sulfate relationships. Geofluids 8:27-34

Bechstädt T, Döhler-Hirner B (1983) Lead-zinc deposits of BleibergKreuth. Am Assoc Petrol Geol Mem 33:55-63

Cerny I (1989) Die karbonatgebundenen Blei-Zink-Lagerstätten des alpinen und außeralpinen Mesozoikums. Die Bedeutung ihrer Geologie, Stratigraphie und Faziesgebundenheit für Prospektion und Bewertung. Archiv Lagerstättenforschung Geol Bundesanstalt 11:5-125

Cerny I, Scherer J, Schroll E (1982) Blei-Zink-Verteilungsmodell in still liegenden Blei-Zink-Revieren der Karavanken. Archiv Lagerstättenforschung Geol Bundesanstalt 2:15-22

Chaler R, Dorronsoro C, Grimalt JO, Agirrezabala LM, FernandezMendiola PA, Garcia-Mondejar J, Gomez-Perez I, Lopez-Horgue M (2005) Distributions of $\mathrm{C}_{22}-\mathrm{C}_{30}$ even-carbon-number nalkanes in Ocean Anoxic Event 1 samples from the BasqueCantabrian basin. Naturwiss 92:221-225

Claypool GE, Holser WT, Kaplan IR, Sakai Z, Zak I (1980) The age curves of sulfur and oxygen isotopes in marine sulfate and their mutual interpretation. Chem Geol 28:199-260

Coplen TB, Krouse HR (1998) Sulphur isotope data consistency improved. Nature 392:32

Cortecci G, Reyes E, Berti G, Casati P (1981) Sulfur and oxygen isotopes in Italian marine sulfates of Permian and Triassic ages. Chem Geol 34:65-79

de Wit R, Grimalt JO, Hernandez-Mariné M (1994) Novel metabolic capacities of sulfate-reducing bacteria, and their activities in microbial mats. In: Stal LJ, Caumette P (eds) Morphological and chemical transformations of Microcoleus chthonoplastes during early diagenesis in hypersaline microbial mats. NATO Advances Science Institute Series, Series G, Ecological Sciences. Springer, Berlin, pp 69-76

Detmers J, Brüchert V, Habicht KS, Kuever J (2001) Diversity of sulfur isotope fractionations by sulfate-reducing prokaryotes. Appl Environm Microbiol 67:888-894
Drovenik M (1983) Mobilization of ore and gangue minerals in some Slovenian mineral deposits. Schr Reihe Erdwiss Komm 6:75-85

Drovenik M, Pungartnik M (1987) Origin of the zinc-lead ore deposit Topla and its particularities. Geologija 30:245-314

Drovenik M, Leskovsek H, Pezdič J, Štrucl I (1970) Sulfur isotope composition in sulfides of some Yugoslav ore deposits. Mining Metallurgy Quarterly, Ljubljana 2-3:153-175 (In Slovene)

Drovenik M, Duhovnik J, Pezdic J (1978) Schwefelisotopenuntersuchungen in slowenischen Erzlagerstätten. Verh Geol B-A 3:301309

Drovenik M, Štrucl I, Pezdič J (1980) Sulfur isotope composition in the lead-zinc ore deposits of the Northern Karavanke. Mining Metallurgy Quarterly, Ljubljana 27:413-436 (In Slovene with Summary in English)

Drovenik M, Pezdič J, Puntgarnik M (1988) Sulfur isotope composition in the lead-zinc ore deposit Topla. Razprave IV, Razreda SAZU 29:113-128

Fodor L, Jelen B, Marton E, Skaberne D, Čar J, Vrabec M (1998) Miocene-Pliocene tectonic evolution of the Slovenian Periadriatic fault: implications for Alpine-Carpathian extrusion models. Tectonics 17:690-709

Fontboté L, Boni M (1994) Sediment-hosted zinc-lead ores-an introduction. In: Fontboté L, Boni M (eds) Sediment-hosted Zn$\mathrm{Pb}$ ores. Special Publ 10 Soc Geol Appl Mineral Deposits. Springer, Berlin-Heidelberg, pp 3-12

Gotzinger MA, Lein R, Park E (2001) Geologie, Mineralogie und Schwefelisotopie ostalpiner "Keuper-Gipse": Vorbericht und Diskussion. Mitteilungen Österr Mineral Ges 146:95-96

Herlec U (2009) Origin of columnar breccia lead and zinc orebodies within the carbonate rocks of the Eastern Alps. Geol Zbo 20:3839 (In Slovene)

Kucha H, Schroll E, Stumpfl EF (2001) Direct evidence for bacterial sulphur reduction in Bleiberg-type deposits. In: Piestrzynski A et al (eds) Mineral deposits at the beginning of the 21st century. Proceedings of joint 6th Biennial SGA-SEG Meeting, 26-29 August 2001. Swetz \& Zeitlinger Publ, Lisse, Kraków, Poland, pp $149-152$

Kucha H, Schroll E, Stumpfl EF (2005) Fossil sulphate-reducing bacteria in the Bleiberg lead-zinc deposit, Austria. Miner Deposita 40:123-126

Kuhlemann J (1994) Zur Pb-Zn Vererzung und spätdiagenetischen Entwicklung des Karawanken-Nordstammes (Östereich/Slowenien). PhD Thesis, Heidelberg 97

Kuhlemann J, Zeeh S (1995) Sphalerite stratigraphy and trace element composition of East Alpine $\mathrm{Pb}-\mathrm{Zn}$ deposits (Drau range, AustriaSlovenia). Econ Geol 90:2073-2080

Kuhlemann J, Vennemann T, Herlec U, Zeeh S, Bechstädt T (2001) Variations of sulfur isotopes, trace element compositions, and cathodoluminescence of Mississippi Valley-type $\mathrm{Pb}-\mathrm{Zn}$ ores from the Drau Range, Eastern Alps (Slovenia-Austria): implications for ore deposition on a regional versus microscale. Econ Geol 96:19311941

Machel HG, Krouse HR, Sassen R (1995) Products and distinguishing criteria of bacterial and thermochemical sulfate reduction. Appl Geochem 10:373-389

Ohmoto H, Goldhaber MB (1997) Sulfur and carbon isotopes. In: Barnes HL (ed) Geochemistry of hydrothermal ore deposits, 3rd edn. Wiley, New York, pp 517-611

Ohmoto H, Lasaga AC (1982) Kinetics of reactions between aqueous sulfates and sulfides in hydrothermal systems. Geochim Cosmochim Acta 46:1727-1745

Ohmoto H, Rye RO (1979) Isotopes of sulfur and carbon. In: Barnes HL (ed) Geochemistry of hydrothermal ore deposits, 2nd edn. Wiley, New York, pp 509-567 
Ohmoto H, Kaiser CJ, Geer KA (1985) Stable isotope geochemistry of ore deposits. In: Herbert HK, Ho SE (eds) Stable isotopes and fluid processes in mineralization. Geology Department \& University Extension, The University of Western Australia, Queensland, pp 70-120

Orr WL (1978) Sulfur in heavy oils, oil sands and oil shales. In: Strausz OP, Loun EM (eds) Oil sand and oil shale chemistry. Verlag Chemie, New York, pp 223-241

Placer L, Vrabec M, Trajanova M (2002) Short overview of geology of surroundings of Mežica. In: Horvat A, Košir A, Vreča P, Brenčič M (eds) 1st. Slovenian Geological Congress, Črna na Koroškem, Excoursion guide. Geological Survey of Slovenia, Ljubljana, pp 3-14 (In Slovene)

Rospondek MJ, Deleeuw JW, Baas M, Vanbergen PF, Leereveld H (1994) The role of organically bound sulfur in stratiform ore sulfide deposits. Org Geochem 21:1181-1191

Schroll E, Rantitsch G (2005) Sulphur isotope patterns from the Bleiberg deposit (Eastern Alps) and their implications for genetically affiliated lead-zinc deposits. Mineral Petrol 84:1-18

Schroll E, Wedepohl KH (1972) Schwefelisotopenuntersuchungen an einigen sulfid- und sulfatmineralen der Blei-Zink Erzlagerstätten Bleiberg/Kreuth, Kärnten. Tschermaks Mineralogisch Petrographische Mitteilungen 17:286-290

Schroll E, Schulz O, Pak E (1983) Sulfur isotope distribution in the $\mathrm{Pb}-$ Zn-deposit Bleiberg (Carinthia, Austria). Miner Deposita 18:17-25

Spangenberg JE, Herlec U (2006) Hydrocarbon biomarkers in the Topla-Mezica zinc-lead deposits, Northern Karavanke/Drau range, Slovenia: paleoenvironment at the site of ore formation. Econ Geol 101:997-1021
Spangenberg JE, Lavrič JV, Herlec U (2001) Inorganic and organic geochemistry of the carbonates hosting the Topla zinc-lead deposit, Slovenia. In: Piestrzynski A et al (eds) Mineral deposits at the beginning of the 21th century. Proceedings of joint 6th Biennial SGA-SEG Meeting, 26-29 August 2001. Swets \& Zeitlinger Publ, Lisse, Kraków, Poland, pp 93-96

Štrucl I (1970) Die Enstehungsbedingungen der Karbonatgesteine und Blei-Zinkvererzungen in den Anisschichten von Topla. Geologija 17:299-397

Strucl I (1974) Stratigraphic and tectonic development of the eastern part of the Northern Karavanke Mts. In Slovene. Geologija 17:299-397

van Dongen BE, Schouten S, Sinninghe Damsté JS (2003) Sulfurization of carbohydrates results in a sulfur-rich, unresolved complex mixture in kerogen pyrolysates. Energy \& Fuels 17:1109-1118

Vrabec M, Herlec U (2007) Short overview of the Mežica surroundings. In: Hlad B, Herlec U (eds) Geological heritage in the south-eastern Europe, field guide. Environmental Agency of the Republic of Slovenia, Ljubljana, pp 43-48

Werne JP, Hollander DJ, Behrens A, Schaeffer P, Albrect P, Sinninghe Damsté JS (2003) Timing of early diagenetic sulfurization of organic matter: a precursor-product relationship in Holocene sediments of the anoxic Cariaco Basin, Venezuela. Geochim Cosmochim Acta 64:1741-1751

Zeeh S, Kuhlemann J, Bechstädt T (1998) The classical Pb-Zn deposits of the eastern Alps (Austria/Slovenia) revisited: MVT deposits resulting from gravity driven fluid flow in the Alpine realm. Geologija 41:257-273 